\title{
Particle mass yield in secondary organic aerosol formed by the dark ozonolysis of $\alpha$-pinene
}

\author{
J. E. Shilling ${ }^{1}$, Q. Chen ${ }^{1}$, S. M. King ${ }^{1}$, T. Rosenoern ${ }^{1}$, J. H. Kroll ${ }^{2}$, D. R. Worsnop ${ }^{2}$, K. A. McKinney ${ }^{3}$, and \\ S. T. Martin ${ }^{1,4}$ \\ ${ }^{1}$ School of Engineering and Applied Sciences, Harvard Univ., Cambridge, MA 02138, USA \\ ${ }^{2}$ Aerodyne Research, Inc., Billerica, MA 08121-3976, USA \\ ${ }^{3}$ Dept. of Chemistry, Amherst College, Amherst MA 01002, USA \\ ${ }^{4}$ Dept. of Earth and Planetary Sciences, Harvard Univ., Cambridge, MA 02138, USA
}

Received: 19 November 2007 - Published in Atmos. Chem. Phys. Discuss.: 14 December 2007

Revised: 7 March 2008 - Accepted: 26 March 2008 - Published: 11 April 2008

\begin{abstract}
The yield of particle mass in secondary organic aerosol (SOA) formed by dark ozonolysis was measured for $0.3-22.8 \mathrm{ppbv}$ of reacted $\alpha$-pinene. Most experiments were conducted using a continuous-flow chamber, allowing nearly constant SOA concentration and chemical composition for several days. For comparison, some experiments were also conducted in batch mode. Reaction conditions were $25^{\circ} \mathrm{C}$, $40 \% \mathrm{RH}$, dry $\left(\mathrm{NH}_{4}\right) \mathrm{SO}_{4}$ seed particles, and excess 1-butanol. The organic particle loading was independently measured by an aerosol mass spectrometer and a scanning mobility particle sizer, and the two measurements agreed well. The observations showed that SOA formation occurred for even the lowest reacted $\alpha$-pinene concentration of 0.3 ppbv. The particle mass yield was 0.09 at $0.15 \mu \mathrm{g} \mathrm{m}^{-3}$, increasing to 0.27 at $40 \mu \mathrm{g} \mathrm{m}^{-3}$. Compared to some results reported in the literature, the yields were 80 to $100 \%$ larger for loadings above $2 \mu \mathrm{g} \mathrm{m}^{-3}$. At lower loadings, the yields had an offset of approximately +0.07 from those reported in the literature. To as low as $0.15 \mu \mathrm{g} \mathrm{m}^{-3}$, the yield curve had no inflection point toward null yield, implying the formation of one or several products having vapor pressures below this value. These observations of increased yields, especially for low loadings, are potentially important for accurate prediction by chemical transport models of organic particle concentrations in the ambient atmosphere.
\end{abstract}

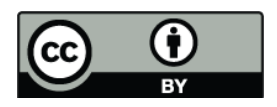

Correspondence to: S. T. Martin (scot_martin@harvard.edu)

\section{Introduction}

The particle component of secondary organic aerosol, which forms from the oxidation of volatile organic compounds (VOC), significantly contributes to the organic particle mass loading in the troposphere (Andreae and Crutzen, 1997; Griffin et al., 1999a; Kanakidou et al., 2005; Tsigaridis and Kanakidou, 2007). Organic particles have diverse atmospheric influences, including effects on visibility, direct radiative forcing, and cloud formation (Chung and Seinfeld, 2002; Seinfeld and Pankow, 2003). Elevated particle concentrations also have deleterious effects on human health, such as increased risk of cardiovascular disease and lung cancer (Dockery et al., 1993; Pope et al., 1995; Miller et al., 2007). Therefore, understanding SOA formation and its contribution to the particle loading of the atmosphere is important.

According to several recent analyses, ambient organic particle mass loadings are 8 to 100 times greater than predicted using chemical transport models (de Gouw et al., 2005; Heald et al., 2005; Volkamer et al., 2006). The models include SOA production as an important source of organic particle mass (Chung and Seinfeld, 2002). These models, informed by laboratory data, are based on equilibrium gasparticle partitioning of the semivolatile products of VOC oxidation (Pankow, 1994a,b; Odum et al., 1996).

Several factors may contribute to the difference between predictions and observations. For instance, the relative contribution of primary emissions to the organic particle mass loading, compared to in situ photochemical production of SOA, is uncertain, especially in urban areas, with estimates ranging from $80 \%$ by Pandis et al. (1992) to $35 \%$ by Zhang et al. (2005) and Volkamer et al. (2006). There is also uncertainty as to whether nonreactive equilibrium partitioning of

Published by Copernicus Publications on behalf of the European Geosciences Union. 
semivolatile products of gas-phase chemistry is a complete mechanism for describing SOA production, both in the laboratory and in the atmosphere. For example, reactions in the particle phase, such as aldol condensation, acid dehydration, and gem-diol reactions can yield products of low volatility, potentially increasing particle mass (Jang et al., 2003; Gao et al., 2004a; Kalberer et al., 2004; Tolocka et al., 2004; Liggio et al., 2005; Gross et al., 2006). In another mechanism, normally volatile species, such as low molecular weight aldehydes, can be taken up by cloud droplets, and aqueous-phase reactions may produce low-volatility molecules that contribute to fine-mode particle mass if the droplet later evaporates (Blando and Turpin, 2000; Chen et al., 2007). Robinson et al. (2007) recently identified the gas-phase oxidation of semivolatile molecules associated with primary diesel emissions as another pathway for SOA production.

Aside from potential SOA sources omitted from the models, another possibility is that the models may underpredict SOA levels because of incomplete laboratory data sets. SOA mass loadings investigated in the laboratory have often been significantly greater than typical ambient loadings of $10 \mu \mathrm{g} \mathrm{m}^{-3}$ or less (Zhang et al., 2007). Extrapolations have therefore been required for the use of laboratory results in regional and global models of SOA production. For example, in the modeling work of Chung and Seinfeld (2002), which is widely used in chemical transport models, the parameterization of Griffin et al. (1999b) was used to describe particle yield from the dark ozonolysis of $\alpha$-pinene. However, the laboratory data used to develop the parameterization were available only as low as $7.4 \mu \mathrm{g} \mathrm{m}^{-3}$ (Hoffmann et al., 1997; Griffin et al., 1999b).

In recognition of the need to study SOA production at loadings below $10 \mu \mathrm{g} \mathrm{m}^{-3}$ and to investigate reaction kinetics, Presto and Donahue (2006) and Ng et al. (2006) developed a novel method for determining particle yield during experiments in real time. Prior to their work, in a typical experiment, the organic precursor VOC and the oxidant were mixed, and the SOA particle volume was measured after the reaction had come close to completion (Hoffmann et al., 1997; Klotz et al., 1998; Griffin et al., 1999b; Koch et al., 2000; Cocker et al., 2001; Jang et al., 2002; Gao et al., 2004b; Kalberer et al., 2004; Iinuma et al., 2005; Paulsen et al., 2005; Kroll et al., 2006). Measurements were made after the complete reaction because of the absence of techniques to detect accurately rapid changes in the VOC concentration and in SOA particle volume. Presto and Donahue (2006) and $\mathrm{Ng}$ et al. (2006) used a proton-transfer-reaction mass spectrometer (PTR-MS) during the initial minutes of VOC oxidation to measure VOC concentrations while they were rapidly changing. The particle volume loading was monitored using a scanning mobility particle sizer (SMPS). During this time period of initial VOC oxidation, the gas-phase concentration and the particle loading were rapidly changing. Therefore, in a single experiment, particle yields were determined from the progressive measurements of the changes in VOC concentra- tion and in particle volume loading. The measurements were made while particle loadings were small at the outset of SOA production, allowing yield determinations for loadings at atmospherically relevant concentrations. Some experimental uncertainty, however, was introduced into the yield measurements at the lowest concentrations of reacted VOC and hence the lowest particle loadings because the SMPS had a characteristic data collection time of 3 to $5 \mathrm{~min}$ and very large fractional changes in the VOC concentration occurred during this time period. The PTR-MS collected data every $20 \mathrm{~s}$.

The yields obtained by this short-time approach (i.e., transient reaction) were similar to those of the traditional longtime approach (i.e., complete reaction) at loadings for which the data sets overlapped, provided that seed particles and ozone levels above $750 \mathrm{ppbv}$ were employed (Pathak et al., 2007a). Otherwise, significant loss of semivolatile organic molecules to the chamber walls was believed to occur, leading to erroneously low yield measurements in those cases. For low loadings (i.e., $<7.4 \mu \mathrm{g} \mathrm{m}^{-3}$ ), Pathak et al. (2007a, b) observed larger yields than predicted by the extrapolation of the parameterizations of Griffin et al. (1999b) and Cocker et al. (2001) for data collected at high loadings (i.e., $>7.4 \mu \mathrm{g} \mathrm{m}^{-3}$ ). Possible explanations included numerical uncertainties in the parameterizations or different physical and chemical mechanisms of SOA production dominant at low mass loading. The results emphasized the importance of conducting experiments at loadings similar to those of the atmosphere so as to capture the behavior of nonlinear processes of SOA production.

An alternative experimental configuration to the shorttime and long-time batch-mode experiments described above is a continuous-flow chamber in which reactants are continuously injected and products are continuously withdrawn from the chamber (Kleindienst et al., 1999; Seinfeld et al., 2003; VanReken et al., 2006; King et al., 2007). Continuousflow operation provides stable conditions over time periods of days to weeks. Semivolatile molecules in the gas phase may come to equilibrium with the organic mass on the walls and in the particles, thereby minimizing the irreversible loss of gas molecules to the walls, which has been identified as a problem in batch-mode experiments (Kroll et al., 2007). The stable conditions of the continuous-flow approach also allow signal integration (typically 4 to $12 \mathrm{~h}$ ) so that the application of demanding techniques, such as the collection of on-line high-resolution mass spectra, is possible. Signal integration improves measurement accuracy and precision, which are especially important for studies at low loadings. Stable conditions act in favor of the use of instruments having relatively slow sampling rates (e.g., an SMPS), potentially resulting in data having lower measurement uncertainties and more accurate yield determinations as a result.

Herein, we present particle mass yields in SOA produced by the dark ozonolysis of $\alpha$-pinene $(0.3-22.8 \mathrm{ppbv})$ for organic mass loadings of 0.15 to $33 \mu \mathrm{g} \mathrm{m}^{-3}$. Both continuousflow and batch-mode data are presented. We focus our 
interpretation on data collected at low organic mass loading, specifically 0.3 to $6.6 \mathrm{ppbv}$ of reacted $\alpha$-pinene and particle mass loadings of 0.15 to $7 \mu \mathrm{g} \mathrm{m}^{-3}$.

\section{Chamber description and operation}

The Harvard Environmental Chamber (HEC) consists of a $4.7 \mathrm{~m}^{3}$ PFA teflon bag housed in a temperature-controlled room. The chamber is coupled to a gas-handling system. Inlet flows of water vapor, ozone, and $\alpha$-pinene in purified air are regulated with MKS mass flow controllers. Dry, clean, hydrocarbon-free air is produced with a pure air generator (Aadco 737). Humidity is controlled by passing clean air at a variable flow rate through a water bubbler $(18 \mathrm{M} \Omega \mathrm{cm})$. A HEPA filter, placed downstream of the bubbler, removes any contaminant particles. Ozone is produced by passing air around an ultraviolet lamp (Jelight 600). A syringe pump (New Era Pump Systems, NE-1000) is used to feed a liquid solution (1:600 v:v, 1:1040 mole:mole) of $\alpha$-pinene (Aldrich, $98 \%$ ) in 1-butanol (Baker, 99.9\%) into a gently warmed glass bulb. The pumping rates are slow enough that most of the organic vapor is released into the glass bulb through evaporation of a sessile drop on the tip of needle. A flow of air sweeps the vapor into the chamber. 1-butanol scavenges $\mathrm{OH}$ radicals generated as products of $\alpha$-pinene ozonolysis. No $\mathrm{NO}_{\mathrm{x}}$ is added to the chamber, and the measured levels are below the instrument detection limit of $1 \mathrm{ppbv}$.

In addition to the gas flows, quasi-monodisperse seed particles are injected into the chamber. The particles are produced from $\left(\mathrm{NH}_{4}\right)_{2} \mathrm{SO}_{4}$ solutions $\left(0.12 \mathrm{~g} \mathrm{~L}^{-1}\right)$ by an atomizer (TSI 3076). The aerosol is diffusion dried to less than $10 \%$ relative humidity, thereby inducing crystallization of the particles. Particles are size-selected at a midpoint mobility diameter using a DMA (TSI, 3070), which is operated at a sheath-to-monodisperse flow ratio of 10:3. The size distribution of the seed particles is centered at $50 \mathrm{~nm}$, with a geometric standard deviation of 1.19-1.25, a number concentration of $5000-8000 \mathrm{~cm}^{-3}$, and a surface-area loading of $6.2-11 \times 10^{7} \mathrm{~nm}^{2} \mathrm{~cm}^{-3}$ (equivalent to $2.9-5.2 \times 10^{-4} \mathrm{~m}^{2}$ in the chamber volume).

There are several diagnostics of the gas and particle composition in the chamber outflow. Ozone, $\mathrm{NO}$, and $\mathrm{NO}_{\mathrm{x}}$ concentrations are monitored by Teledyne $400 \mathrm{E}$ and Teledyne $200 \mathrm{E}$ instruments, respectively. Relative humidity and temperature are measured with a Rotronics sensor (Hygroclip SC05). The mass loading and the vacuum-aerodynamicdiameter size distribution of the particles are measured using an Aerodyne high-resolution time of flight mass spectrometer (HR-ToF-AMS) (Jayne et al., 2000; DeCarlo et al., 2006). The electric-mobility-diameter size distribution is measured using a TSI SMPS (3081 DMA, 3772 CPC) operated with recirculating sheath-air flow. Recirculation ensures that after sufficient time organic molecules in the sheath air, the particles deposited on the internal HEPA filter, and the aerosol in

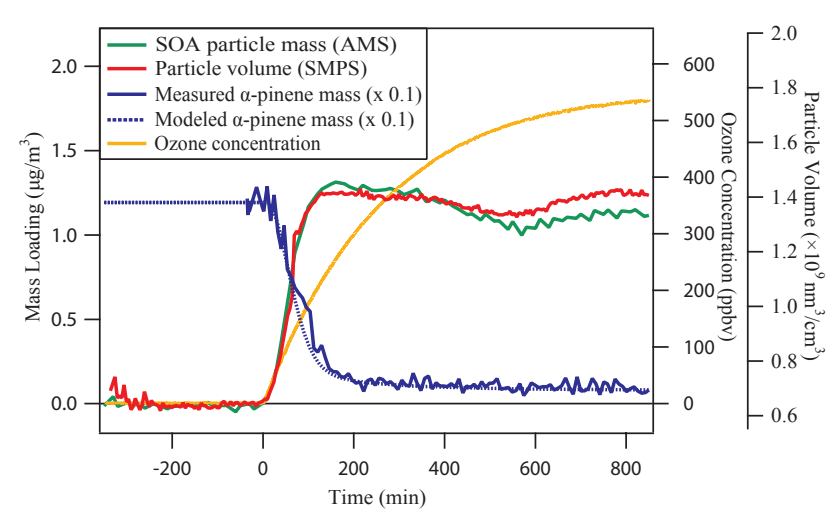

Fig. 1. Evolution of ozone concentration, SOA particle mass loading, SOA particle volume loading, and measured and modeled $\alpha$ pinene concentration toward steady-state during a continuous-flow experiment. Particle and $\alpha$-pinene $(\times 0.1)$ mass loadings are shown on the left axis, ozone concentration is shown on the inner-right axis, and particle volume loading is shown on the outer-right axis. Corrections for particle loss to the walls are not applied to the shown data. $\alpha$-pinene is injected and equilibrated (2.1 ppbv) prior to injection of ozone. Further conditions are given in Table 1. The Appendix provides information on instrument calibration and on calculation of particle loadings from the data of the AMS and the SMPS.

the chamber outflow reach equilibrium. An Ionicon protontransfer reaction mass spectrometer (PTR-MS) was available during several of the experiments for the analysis of gasphase hydrocarbons (Lindinger et al., 1998).

In the continuous-flow mode of the HEC, the outflow balances the inflow (Kleindienst et al., 1999; Seinfeld et al., 2003). Ozone, water vapor, seed particles, OH scavenger, and precursor VOC are continuously input into the chamber during the course of the experiments and SOA particles are continuously monitored in the chamber outflow. An experiment is run for an indefinite time period of days to weeks, going through an initial transient period of 12 to $24 \mathrm{~h}$ until reactants and products reach their steady-state concentrations. Chamber inflow-outflow is balanced by a feedback control that maintains the bag at a constant overpressure of 30 mTorr relative to its surroundings. As a result of the overpressure, the bag walls are relatively quiescent, minimizing the mass transfer of gases and particles to the walls. Ozone concentration and relative humidity are also maintained at constant values through feedback controls. The total flow rate of $21.1 \mathrm{sLpm}$, made up of 16, 3, 0.1, and $2 \mathrm{sLpm}$ for the respective air flows of water vapor, seed particles, ozone, and precursor VOC mixed with $\mathrm{OH}$ scavenger, corresponds to a residence time of $3.4 \mathrm{~h}$ in the bag. The air, water vapor, seed, and ozone flows are mixed in a single inlet and introduced into the center of chamber. The precursor VOC mixed with $\mathrm{OH}$ scavenger in a carrier gas flow is injected into the chamber through a separate inlet which is oriented perpendicular to and approximately $1 \mathrm{~m}$ away from the first inlet. Sampling 


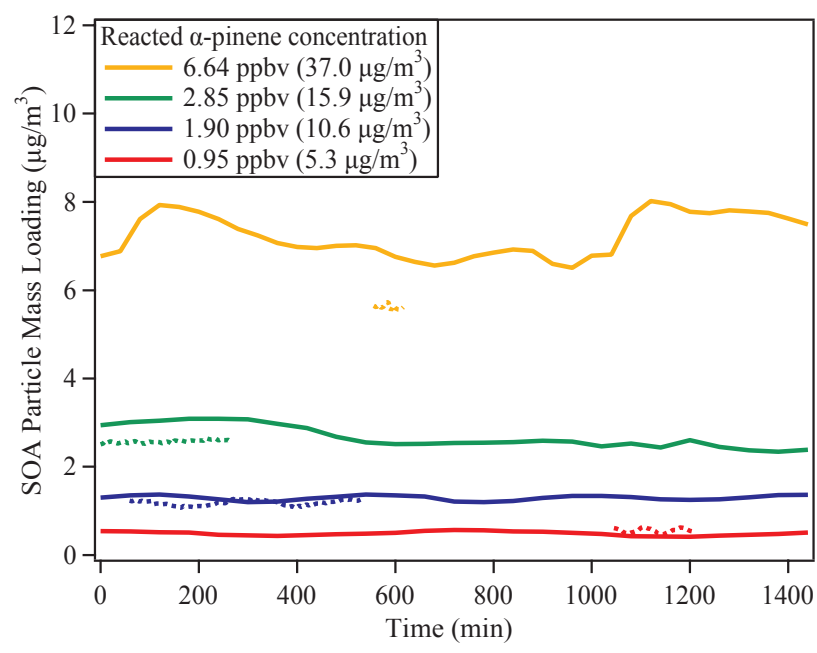

Fig. 2. Time trace of the SOA particle mass loading measured by the AMS (solid lines) and calculated from the SMPS volume measurements (dotted line) using measured $\rho_{\mathrm{SOA}}$ for four different reacted $\alpha$-pinene concentrations. Corrections for particle loss to the walls are not applied to the shown data. Experimental conditions are the same as for Fig. 1, except that 300 ppbv ozone is employed. A continuous SMPS record is not available because this instrument was also used for other functions.

flows are drawn from the center of the chamber along the axis perpendicular to both inlet flows. The teflon bag is periodically cleaned, especially before conducting experiments for the lowest SOA mass loadings, by exposure to high ozone concentrations (ca. $1 \mathrm{ppm}$ ) for at least $24 \mathrm{~h}$ at $40^{\circ} \mathrm{C}$, followed by flushing with clean air for several hours. Following cleaning, particle concentrations in the chamber outflow are below $5 \mathrm{~cm}^{-3} . \alpha$-pinene is the precursor VOC used in the experiments of the present study.

\section{Results and discussion}

The evolution toward steady-state of the $\alpha$-pinene concentration measured by the PTR-MS, the organic mass loading measured by the AMS, the particle volume loading measured by the SMPS, and the ozone concentration is shown in Fig. 1 for a continuous-flow experiment. Prior to time zero of Fig. 1, $\alpha$-pinene and seed particles were introduced into the chamber and allowed to come to steady-state. The measured concentration of $\alpha$-pinene (2.1 ppbv, $11.9 \mu \mathrm{g} \mathrm{m}^{-3}$ ) agreed with the concentration expected based on the syringe injection rate into the bulb reservoir and the dilution ratio when entering the chamber. Prior to the injection of ozone, the mass loading of organic particles was below the detection limit of the AMS $\left(0.02 \mu \mathrm{g} \mathrm{m}^{-3}\right)$ (DeCarlo et al., 2006). The particle volume loading measured at this time by the SMPS $\left(0.68 \times 10^{9} \mathrm{~nm}^{3}\right.$-particles $\mathrm{cm}^{-3}$-air $)$ corresponded to the seed sulfate particles.
At time zero, the ultraviolet lamp of the ozone generator was turned on, initiating injection of ozone into the chamber. The approach of ozone concentration to a steady-state value of 535 ppbv over a period of $800 \mathrm{~min}$ is apparent in Fig. 1. Concomitantly, SOA production began, as independently indicated by increases in the organic particle mass loading and the particle volume loading. The $\alpha$-pinene concentration also decreased. There was no time delay between the consumption of $\alpha$-pinene and the onset of particle growth.

After ca. $600 \mathrm{~min}$, steady-state conditions were obtained for $\alpha$-pinene. The PTR-MS measurements showed that 8.0 $( \pm 1) \%$ of the $\alpha$-pinene introduced into the chamber exited without reaction. This amount of residual $\alpha$-pinene in the chamber outflow agreed well with a calculated value based on the measured ozone concentration, a rate constant of $8.66 \times 10^{-17} \mathrm{~cm}^{3}$ molecule ${ }^{-1}$ for $\alpha$-pinene ozonolysis (Calvert et al., 2000), and a residence time of $3.4 \mathrm{~h}$ in the chamber. Moreover, the kinetic trace of the model shown in Fig. 1 agreed well with the time-dependent observations. The model was not scaled to the measurements but rather used known rate constants and inflow/outflow rates from the chamber. The agreement between the measurements and the model is evidence both that there was effective mixing of $\alpha$-pinene and ozone within the chamber and that $\mathrm{OH}$ radicals were adequately scavenged by 1 butanol. More than $99 \%$ of the $\mathrm{OH}$ radicals were expected to be scavenged by 1-butanol based upon the relative concentrations of 1-butanol and $\alpha$-pinene and the rate constants of $\mathrm{OH}$ with these compounds $\left(8.28 \times 10^{-12} \mathrm{~cm}^{3}\right.$ molecule ${ }^{-1}$ and $5.37 \times 10^{-11} \mathrm{~cm}^{3}$ molecule $^{-1}$, respectively) (Calvert et al., 2000; Cavalli et al., 2002),

The mass loadings measured by the AMS ( $\left.\Delta M_{\mathrm{AMS}}\right)$, as well as the mass loadings determined from the SMPS volume loading after accounting for the sulfate baseline and the measured particle density (Fig. S1, http://www.atmos-chem-phys.net/8/2073/2008/ acp-8-2073-2008-supplement.pdf), are shown in Fig. 2 for separate experiments conducted at $0.95,1.9,2.85$, and $6.64 \mathrm{ppbv}$ reacted $\alpha$-pinene. The data were recorded at least $24 \mathrm{~h}$ after the initial transient period shown Fig. 1 (i.e., the time axis is not conserved in moving from Fig. 1 to Fig. 2). The steady-state data shown in Fig. 2 are broadly representative of those used to calculate $\Delta M_{\mathrm{AMS}}$ in this study. Operation of the HEC in continuous-flow mode maintained approximately stable particle loadings, as represented in Fig. 2, for week-long time periods. Regular fluctuations of up to $20 \%$ were caused by the occasional release of a sessile $\alpha$-pinene/butanol drop from the syringe needle and by chamber dynamics. In addition to providing a metric for the stability of the continuous-mode operation, the data of Fig. 2 also show that the increase of organic particle loading was not linear with $\alpha$-pinene concentration from 0.95 to $6.64 \mathrm{ppbv}$.

The steady-state SOA particle mass yields $\left(Y^{s s}\right)$ determined from the data in Fig. 2, as well as from similar data 
at other $\alpha$-pinene concentrations (Table 1), are shown in Fig. 3 (red and blue circles). Yields were calculated as $Y^{s s}=\Delta M^{s s} / \Delta H C^{s s}$, where $\Delta M^{s s}\left(\mu \mathrm{g} \mathrm{m}^{-3}\right)$ was the steadystate organic-particle loading and $\Delta H C^{s s}\left(\mu \mathrm{g} \mathrm{m}^{-3}\right)$ was the reacted concentration of $\alpha$-pinene. As an estimate of experimental variability, experiments at $0.95,1.90$, and $2.85 \mathrm{ppbv}$ $\alpha$-pinene were each repeated three times, and the yield of each varied less than 20\%. The yields in Fig. 3 and Table 1 are lower limits of the actual yields because wall loss, which reduced the particle loading, was not accounted for. Wallloss corrections are discussed further below.

Two batch-mode experiments were conducted to provide an in-lab comparison between continuous-flow and batchmode yields. Temperature, relative humidity, ozone, and seed particles were adjusted to their desired levels in the bag, after which inflows were turned off. A pulse of clean air swept $\alpha$-pinene and either 1-butanol or 2-butanol from the heated bulb reservoir into the chamber, after which this inflow was also shut off. The subsequent production of particle mass resulting from $\alpha$-pinene ozonolysis was then monitored. Following the approach described by Presto and Donahue (2006) and Ng et al. (2006), we calculated yield in 5min time steps using simultaneous measurements of the $\alpha$ pinene concentration via the PTR-MS and the particle loading via both the AMS and the SMPS. As shown in Fig. 3, the yields from these batch-mode experiments (green and orange triangles) agreed well with those obtained in the continuousflow mode.

The results shown in Fig. 3 and Table 1 indicate that there was significant SOA production at low ppbv levels of reacted $\alpha$-pinene. For example, $1.9 \mathrm{ppbv}\left(10.6 \mu \mathrm{g} \mathrm{m}^{-3}\right)$ of reacted $\alpha$-pinene produced $0.9 \mu \mathrm{g} \mathrm{m}^{-3}$ of SOA particle mass, corresponding to $Y^{s s}=0.09$. This example corresponds to the steady-state portion of the time trace of the data shown in Fig. 1. The yield increased with loading, ranging from 0.09 to 0.27 for loadings of 0.15 to $40 \mu \mathrm{g} \mathrm{m}^{-3}$. Also shown in Fig. 3 is the two-product fit through the data. Table 2 lists the fit coefficients for two common parameterizations of yields, though only the two-product fit is shown in Fig. 3 (Odum et al., 1996, 1997; Seinfeld and Pankow, 2003; Presto and Donahue, 2006). The Appendix provides the mathematical forms of the fitting functions.

Our findings can be compared to several recent reports in literature. In our study, the yield curve had no inflection point toward null yield to as low as $0.15 \mu \mathrm{g} \mathrm{m}^{-3}$, indicating the formation of one or several products having vapor pressures below this value and reflected in the large value of $K_{1}$ of $100 \mathrm{~m}^{3} \mu \mathrm{g}^{-1}$ in the two-product fit (Table 2). Verheggen et al. (2007) observed a similar result to below $0.5 \mu \mathrm{g} \mathrm{m}^{-3}$ provided that the total condensable product mass including some gas-phase species was considered. Pathak et al. (2007b), however, observed curvature toward zero yield (cf. data points in Fig. 4). A related finding is that Pathak et al. (2007b) did not observe particle growth below $1 \mathrm{ppbv}$ reacted $\alpha$-pinene. In our work, however, we observed signif-
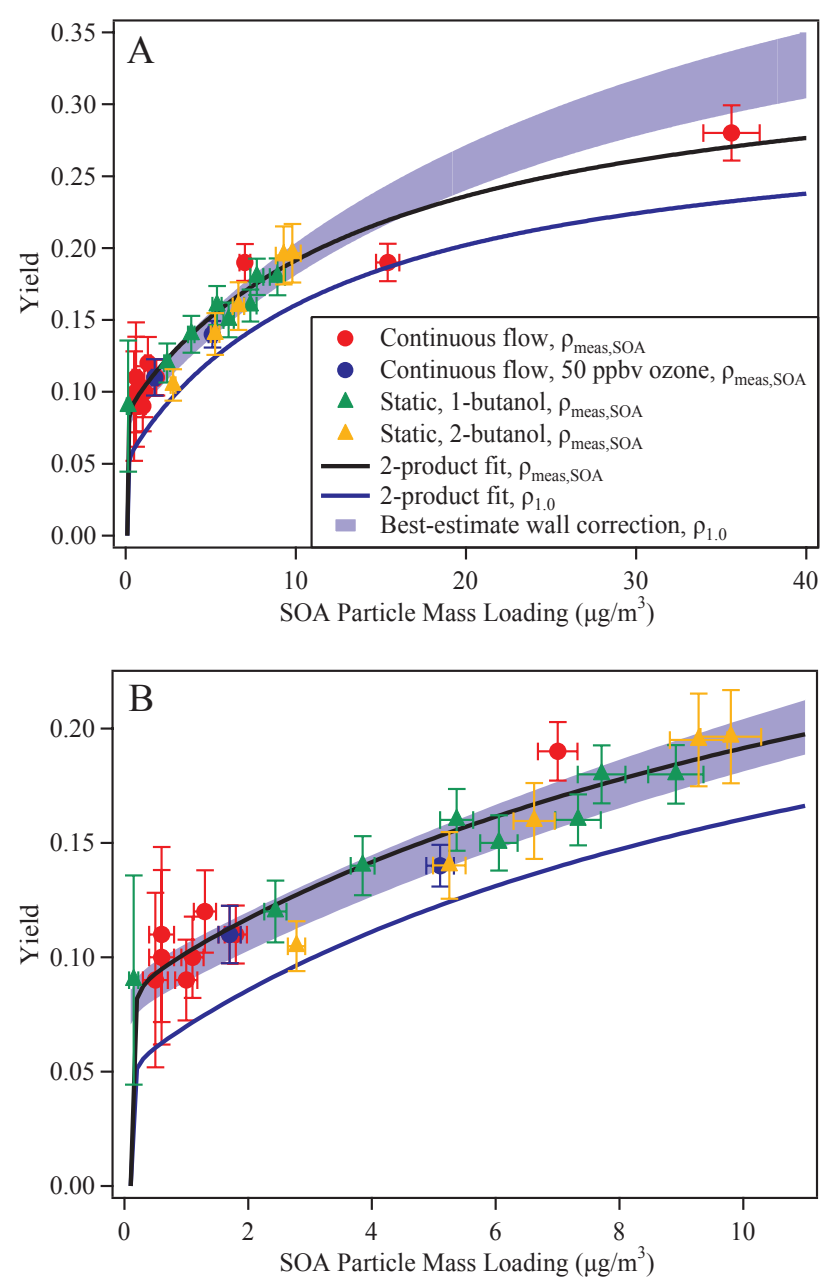

Fig. 3. Particle mass yield of SOA produced by the dark ozonolysis of $\alpha$-pinene in continuous-flow and batch-mode experiments. Panel (A) shows the full range of data from 0 to $40 \mu \mathrm{g} \mathrm{m}^{-3}$ organic loading. Panel (B) shows an expanded view from 0 to $10 \mu \mathrm{g} \mathrm{m}^{-3}$. Values of the data points correspond to $Y_{\text {AMS }}$ of Table 1. The SMPS data $Y_{\text {SMPS }}$ give similar results (cf. Fig. 5). The black line shows the fit for the parameters given in Table 3 for $\rho_{\text {SOA }}$. The blue line shows the fit after the data are normalized to $\rho_{1.0}$, as done to facilitate comparison of our data to literature data (cf. Fig. 4). The shaded blue area shows the best-estimate yield values for $\rho_{1.0}$ after correction for particle wall loss.

icant growth for $0.3 \mathrm{ppbv}$, which was the lowest value of our study. By chemical argument, organic molecules having vapor pressures low enough to condense under these conditions might be expected to have a high fractional oxygen content. In agreement with this supposition, Tolocka et al. (2006) and Heaton et al. (2007) found that freshly nucleated $\alpha$-pinene ozonolysis particles were highly oxygenated. The AMS mass spectra recorded in our study, which will be the subject of a detailed future publication, showed that the organic mass was increasingly oxygenated as particle loading decreased. 
Table 1. Experimental conditions and results for SOA particle production from the dark ozonolysis of $\alpha$-pinene. Yields were calculated as $Y=\Delta M / \Delta \mathrm{HC}$, where $\Delta M\left(\mu \mathrm{g} \mathrm{m}^{-3}\right)$ was the organic particle mass loading and $\Delta \mathrm{HC}\left(\mu \mathrm{g} \mathrm{m}^{-3}\right)$ was the reacted concentration of $\alpha$ pinene. No corrections were made for wall losses for the values included in this table. The experiments were performed under the following conditions: $298( \pm 1) \mathrm{K}, 40( \pm 2) \% \mathrm{RH},<1 \mathrm{ppbv} \mathrm{NO}$, dry $\left(\mathrm{NH}_{4}\right) \mathrm{SO}_{4}$ seed particles $\left(5000\right.$ to $8000 \mathrm{~cm}^{-3}$ and $_{6.2}$ to $\left.11 \times 10^{7} \mathrm{~nm}^{2} \mathrm{~cm}^{-3}\right)$, and 1- or 2-butanol as an $\mathrm{OH}$ radical scavenger at a molar concentration of 1040 times that of $\alpha$-pinene. Data averaging times for $\Delta M_{\mathrm{AMS}}$ typically ranged between 4 and $12 \mathrm{~h}$ in the continuous-flow mode. Data were averaged for $5 \mathrm{~min}$ in the batch-mode experiments. The corresponding averaging times for $\Delta M_{\text {SMPS }}$ were $1-4 \mathrm{~h}$ in the continuous-flow mode and 5 min for the batch-mode experiments.

\begin{tabular}{|c|c|c|c|c|c|c|c|c|c|}
\hline Date & Mode & $\mathrm{O}_{3}$ (ppbv) & $\Delta \mathrm{HC}(\mathrm{ppbv})$ & $\Delta \mathrm{HC}\left(\mu \mathrm{g} \mathrm{m}^{-3}\right)$ & $\Delta M_{\mathrm{AMS}}\left(\mu \mathrm{g} \mathrm{m}^{-3}\right)$ & $\Delta M_{\text {SMPS }}\left(\mu \mathrm{g} \mathrm{m}^{-3}\right)^{a}$ & $\rho_{\text {meas, SOA }}\left(\mathrm{g} \mathrm{cm}^{-3}\right)$ & $Y_{\mathrm{AMS}}$ & $Y_{\text {SMPS }}$ \\
\hline $12 / 10 / 2006$ & continuous & 300 & 22.77 & 126.93 & 35.64 & - & 1.23 & 0.28 & - \\
\hline 1/8/2007 & continuous & 300 & 2.85 & 15.87 & 1.67 & 1.29 & 1.65 & 0.11 & 0.08 \\
\hline $1 / 10 / 2007$ & continuous & 300 & 14.23 & 79.33 & 15.42 & 8.79 & 1.23 & 0.19 & 0.11 \\
\hline $1 / 24 / 2007$ & continuous & 300 & 6.64 & 37.02 & 6.97 & 5.74 & 1.42 & 0.19 & 0.15 \\
\hline $1 / 31 / 2007$ & continuous & 300 & 0.95 & 5.29 & 0.55 & 0.45 & 1.67 & 0.10 & 0.08 \\
\hline $2 / 5 / 2007$ & continuous & 300 & 1.90 & 10.58 & 1.26 & 1.19 & 1.66 & 0.12 & 0.11 \\
\hline $2 / 8 / 2007$ & continuous & 300 & 0.95 & 5.29 & 0.50 & 0.67 & 1.73 & 0.09 & 0.13 \\
\hline $2 / 11 / 2007$ & continuous & 300 & 1.90 & 10.58 & 0.96 & 1.33 & 1.64 & 0.09 & 0.13 \\
\hline $2 / 23 / 2007$ & continuous & 50 & 2.85 & 15.87 & 1.74 & 1.52 & 1.60 & 0.11 & 0.10 \\
\hline $2 / 26 / 2007$ & continuous & 50 & 6.64 & 37.02 & 5.07 & 3.65 & 1.53 & 0.14 & 0.10 \\
\hline $4 / 19 / 2007$ & continuous & 535 & 1.90 & 10.58 & 1.09 & 0.94 & 1.56 & 0.10 & 0.09 \\
\hline $4 / 20 / 2007$ & continuous & 300 & 2.85 & 15.87 & 1.81 & 1.45 & 1.56 & 0.11 & 0.09 \\
\hline $4 / 21 / 2007$ & continuous & 300 & 0.95 & 5.29 & 0.60 & 0.89 & 1.51 & 0.11 & 0.17 \\
\hline $4 / 29 / 2007$ & batch & 300 & 0.30 & 1.65 & 0.15 & $0.17^{\mathrm{b}}$ & - & 0.09 & 0.10 \\
\hline $4 / 29 / 2007$ & batch & 300 & 3.77 & 20.99 & 2.44 & 3.67 & 1.32 & 0.12 & 0.15 \\
\hline $4 / 29 / 2007$ & batch & 300 & 5.06 & 28.21 & 3.85 & 5.45 & 1.25 & 0.14 & 0.14 \\
\hline $4 / 29 / 2007$ & batch & 300 & 6.13 & 34.17 & 5.37 & 6.50 & 1.30 & 0.16 & 0.17 \\
\hline $4 / 29 / 2007$ & batch & 300 & 7.01 & 39.08 & 6.05 & 7.35 & 1.26 & 0.15 & 0.17 \\
\hline $4 / 29 / 2007$ & batch & 300 & 7.74 & 43.14 & 7.71 & 7.54 & 1.27 & 0.18 & 0.18 \\
\hline $4 / 29 / 2007$ & batch & 300 & 8.34 & 46.49 & 7.33 & 8.32 & 1.23 & 0.16 & 0.17 \\
\hline $4 / 29 / 2007$ & batch & 300 & 8.83 & 49.25 & 8.91 & 8.20 & 1.30 & 0.18 & 0.17 \\
\hline $5 / 17 / 2007^{\mathrm{c}}$ & batch & 300 & 4.76 & 26.56 & 2.78 & - & - & 0.10 & - \\
\hline $5 / 17 / 2007^{\mathrm{c}}$ & batch & 300 & 6.71 & 37.43 & 5.25 & - & - & 0.14 & - \\
\hline $5 / 17 / 2007^{\mathrm{c}}$ & batch & 300 & 7.44 & 41.49 & 6.62 & - & - & 0.16 & - \\
\hline $5 / 17 / 2007^{\mathrm{c}}$ & batch & 300 & 8.54 & 47.60 & 9.28 & - & - & 0.19 & - \\
\hline $5 / 17 / 2007^{\mathrm{c}}$ & batch & 300 & 8.95 & 49.89 & 9.80 & - & - & 0.20 & - \\
\hline
\end{tabular}

a $\Delta M_{\text {SMPS }}$ is calculated as the product of the indicated SOA density and the change in volumetric loading.

${ }^{\mathrm{b}}$ Due to insufficient signal in the P-TOF mode of the AMS, the SOA density could not be calculated for this experiment. Instead, a density of 1.64 (i.e., the average density of the 1/31,2/8, and 4/21 experiments) was employed.

c 2-butanol was employed as the $\mathrm{OH}$ radical scavenger. SMPS data were not recorded. Data from this experiment were excluded from the parameterizations.

Table 2. Empirical parameters describing the particle mass yield of SOA produced in continuous-flow mode for the dark ozonolysis of $\alpha$-pinene. Parameters, both for measured density $\rho_{\text {meas,SOA }}$ and normalized density $\rho_{1.0}$ of $1.0 \mathrm{~g} \mathrm{~cm}^{-3}$, are shown for a two-product model (Odum et al., 1996) and a basis-set model (Donahue et al., 2005). Wall-loss-corrected parameters are also provided for $\rho_{1.0}$. Equations for making use of these parameters are given in the Appendix. The $K_{j}$ values shown in the table correspond to the $C_{j}^{*}$ values commonly used in the basis set model as $K_{j}=1 / C_{j}^{*}$. Model fits are plotted in Fig. 3 .

\begin{tabular}{|c|c|c|c|c|c|c|c|c|}
\hline & $\alpha_{1}$ & $\alpha_{2}$ & $\alpha_{3}$ & $\alpha_{4}$ & $K_{1}\left(\mathrm{~m}^{3} \mu \mathrm{g}^{-1}\right)$ & $K_{2}\left(\mathrm{~m}^{3} \mu \mathrm{g}^{-1}\right)$ & $K_{3}\left(\mathrm{~m}^{3} \mu \mathrm{g}^{-1}\right)$ & $K_{4}\left(\mathrm{~m}^{3} \mu \mathrm{g}^{-1}\right)$ \\
\hline \multicolumn{9}{|l|}{$\rho_{\text {meas }, \mathrm{SOA}}$} \\
\hline Two-Product Model & 0.088 & 0.259 & - & - & 100 & 0.067 & - & - \\
\hline Basis Set & 0.08 & 0.019 & 0.18 & 0.03 & 10 & 1 & 0.1 & 0.01 \\
\hline \multicolumn{9}{|l|}{$\rho_{1.0}$} \\
\hline Two-Product Model & 0.054 & 0.242 & - & - & 100 & 0.079 & - & - \\
\hline Wall-corrected, lower limit & 0.076 & 0.373 & - & - & 100 & 0.039 & - & - \\
\hline Wall-corrected, upper limit & 0.093 & 0.459 & - & - & 100 & 0.032 & - & - \\
\hline Basis Set & 0.059 & 0.007 & 0.18 & 0.03 & 10 & 1 & 0.1 & 0.01 \\
\hline
\end{tabular}



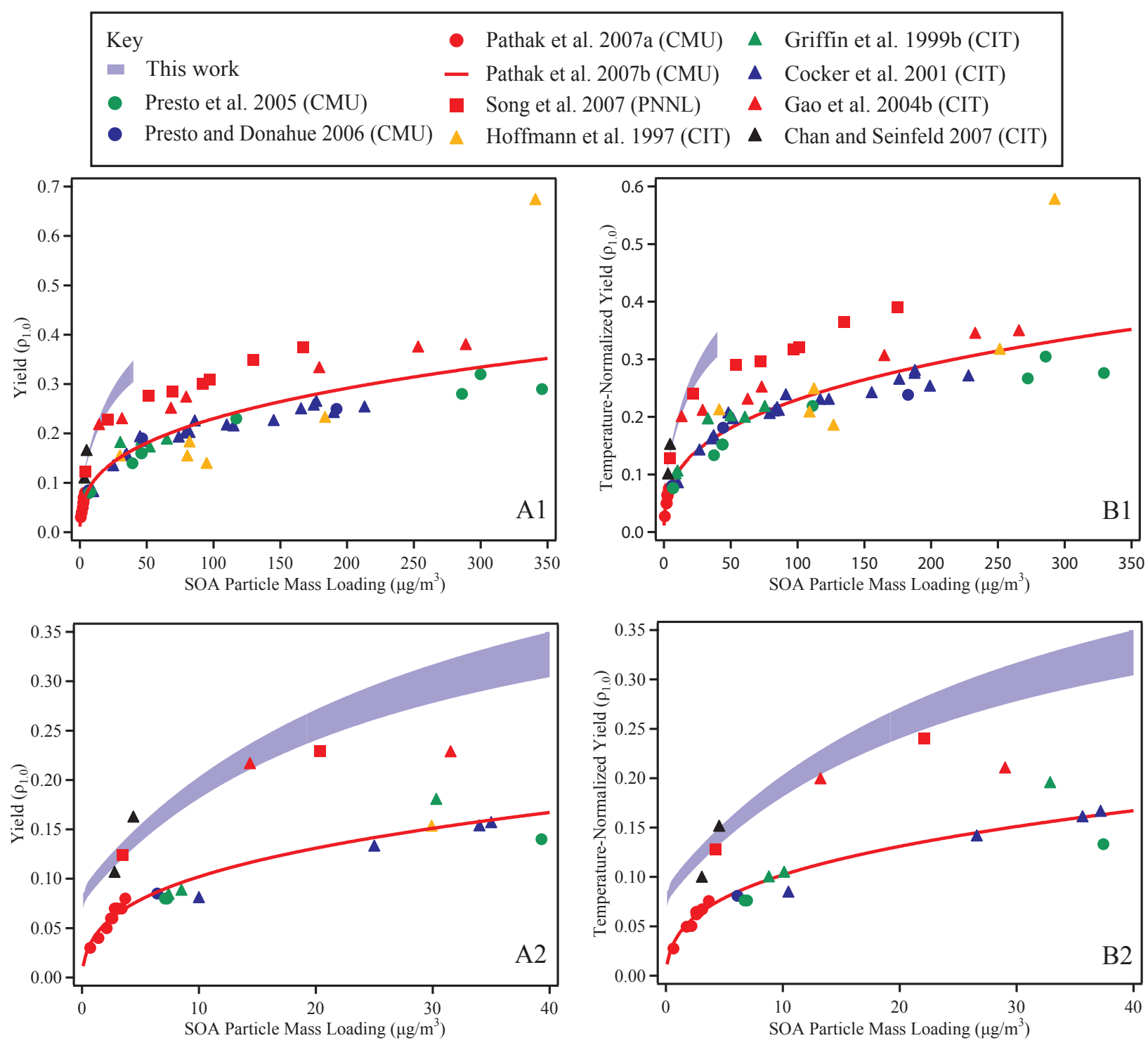

Fig. 4. Comparison of yields obtained in this work to those of other studies for the dark ozonlysis of $\alpha$-pinene (Table 3). Data shown in panels (A1) and (A2) are as reported by the original researchers, with the exception of the data of Gao et al. (2004b) and Song et al. (2007). We adjusted these data to $\rho_{1.0}$ to facilitate the comparison with the other studies. We adjusted the data shown in panels (B1) and (B2) to $298 \mathrm{~K}$ using a temperature correction of $1.6 \%$ per K, as recommended by Pathak et al. (2007a), to allow comparisons among the studies.

Our yields can also be quantitatively compared to those reported in earlier studies of the dark ozonolysis of $\alpha$-pinene (Hoffmann et al., 1997; Griffin et al., 1999b; Cocker et al., 2001; Gao et al., 2004b; Presto et al., 2005; Presto and Donahue, 2006; Chan and Seinfeld, 2007; Pathak et al., 2007a, b; Song et al., 2007). Table 3 lists and compares the experimental conditions employed. These studies reported results using SMPS measurements of particle volume loading and a density of $1.0 \mathrm{~g} \mathrm{~cm}^{-3}$. Therefore, to facilitate a comparison of our data to the results in literature, we adjusted our yield data to an organic density of $1.0 \mathrm{~g} \mathrm{~cm}^{-3}$ (viz. $\rho_{1.0}$ ). The resulting two-product fit is shown in Fig. 3 (blue line; no wall-loss corrections), and the fit coefficients are given in Table 2.
The deposition of particles to the walls of environmental chambers reduces the organic particle mass (McMurry and Grosjean, 1985; Kroll et al., 2007). The literature studies of Table 3, represented by the data in Fig. 4, therefore corrected the yields for deposition of particles to the walls. To similarly address depositional wall loss and thereby correct the apparent yields of our study, we measured the loss rate of dry, monodisperse ammonium sulfate particles in the continuousflow mode of the HEC, obtaining 0.17 to $0.09 \mathrm{~h}^{-1}$ for 50 through $150 \mathrm{~nm}$ particles. The density-normalized yields 
Table 3. Comparison of the experimental conditions of this work with those of other studies on the particle mass yield of SOA produced in the dark ozonlysis of $\alpha$-pinene. The yields of these studies are shown as data points in Fig. 4.

\begin{tabular}{|c|c|c|c|c|c|c|c|c|}
\hline Reference & $\begin{array}{l}\text { Temperature } \\
(\mathrm{K})\end{array}$ & $\begin{array}{l}\text { Relative Humidity } \\
(\%)\end{array}$ & Seed & OH Scavenger & $\begin{array}{l}\text { Ozone } \\
\text { (ppbv) }\end{array}$ & $\begin{array}{l}\Delta \mathrm{HC} \\
(\mathrm{ppbv})\end{array}$ & $\begin{array}{l}\rho_{\mathrm{SOA}} \\
\left(\mathrm{g} \mathrm{cm}^{-3}\right)\end{array}$ & $\begin{array}{l}\Delta M \\
\left(\mu \mathrm{g} \mathrm{m}^{-3}\right)\end{array}$ \\
\hline Hoffmann et al. (1997) ${ }^{a}$ & $289.3-322.1$ & NA & $\left(\mathrm{NH}_{4}\right)_{2} \mathrm{SO}_{4}(\mathrm{~s})$ & none & $210-327$ & $38-154.1$ & NA & $29.9-341$ \\
\hline Griffin et al. (1999b) & 303.3-309.9 & 5 & $\left(\mathrm{NH}_{4}\right)_{2} \mathrm{SO}_{4}(\mathrm{~s})$ & 2-butanol & $67-260$ & $16.7-65.0$ & 1.0 & $7.4-65.1$ \\
\hline Cocker et al. $(2001)^{b}$ & $301.2-302.9$ & $<2,39-49.2$ & $\begin{array}{l}\text { none, }\left(\mathrm{NH}_{4}\right)_{2} \mathrm{SO}_{4}(\mathrm{~s}) \text {, } \\
\text { and } \mathrm{NH}_{4} \mathrm{HSO}_{4}\end{array}$ & 2-butanol & $130-600$ & $22.6-212.3$ & 1.0 & $10-213$ \\
\hline Gao et al. $(2004 b)^{c}$ & 293 & 55 & $\mathrm{MgSO}_{4}(\mathrm{aq})$ & cyclohexane & $24-270$ & $12-135$ & $1.4^{\mathrm{h}}$ & $20-404$ \\
\hline Presto et al. $(2005)^{\mathrm{d}}$ & 295 & $<10$ & none & 2-butanol & $160-605$ & $15.0-210$ & 1.0 & $7.08-346$ \\
\hline Presto and Donahue $(2006)^{\mathrm{e}}$ & 295 & $<10$ & none & 2-butanol & $260-350$ & $13.4-135$ & 1.0 & $6.43-192$ \\
\hline Pathak et al. $(2007 a)^{f}$ & $288-313$ & $<10$ & none, $\left(\mathrm{NH}_{4}\right)_{2} \mathrm{SO}_{4}(\mathrm{~s})$ & 2-butanol & $750-3100$ & $3.7-8.5$ & 1.0 & $0.7-3.7$ \\
\hline Pathak et al. (2007b) & 288 & 65 & $\left(\mathrm{NH}_{4}\right)_{2} \mathrm{SO}_{4}$ & 2-butanol & 250 & 38 & 1.0 & 46.0 \\
\hline Song et al. $(2007)^{g}$ & $300.6-301.7$ & $<2$ & none & cyclohexane & $46-369$ & $5.9-81.1$ & $1.2^{\mathrm{h}}$ & $5.0-205.9$ \\
\hline Chan and Seinfeld (2007) & 293 & $<7$ & none, $\left(\mathrm{NH}_{4}\right)_{2} \mathrm{SO}_{4}(\mathrm{~s})$ & cyclohexane & 90 & $5.4-5.6$ & 1.0 & $3.34-5.0$ \\
\hline This work & 298 & 40 & $\left(\mathrm{NH}_{4}\right)_{2} \mathrm{SO}_{4}(\mathrm{~s})$ & 1- and 2- butanol & $50,300,535$ & $0.3-22.8$ & $1.23-1.73^{\mathrm{h}}$ & $0.15-35.6$ \\
\hline
\end{tabular}

a The majority of the data was collected at $319.3-322.1 \mathrm{~K}$. One point was collected at $289.3 \mathrm{~K}$.

$\mathrm{b}$ We do not include the data collected using aqueous seed particles.

c We do not include the data collected using acidic seed particles.

$\mathrm{d}$ We include in our analysis only the experiments for which $[\mathrm{VOC}] /\left[\mathrm{NO}_{\mathrm{x}}\right]>15$ and which were conducted in the dark.

e We include in our analysis only experiments classified as " $\alpha$-pinene $+\mathrm{O}_{3}$, dark".

$\mathrm{f}$ We include in our analysis only data collected for ozone concentrations of $750 \mathrm{ppbv}$ or greater in the presence of seed particles and of $1500 \mathrm{ppbv}$ or greater in their absence because Pathak et al. (2007a) observed that yields depend on seed particles and ozone concentration under some conditions.

$\mathrm{g}$ We do not include the data collected using organic seed particles.

$\mathrm{h}$ Yields shown in Fig. 4 are normalized to $\rho_{1.0}$.

were then wall-loss corrected using Eq. (1):

$Y_{\mathrm{corr}}^{s s}=Y^{s s}\left(1+\frac{V \beta}{F}\right)$

where $F$ was the total flow rate through the chamber (21.1 sLpm), $V$ was the chamber volume $(4711 \mathrm{~L})$, and $\beta$ was the wall loss coefficient $\left(0.17\right.$ or $\left.0.09 \mathrm{~h}^{-1}\right)$. In applying Eq. (1), we assumed that the particle-wall-loss rate was firstorder. The best-estimate particle yields for $\rho_{1.0}$ are shown in Figs. 3 and 4 as the shaded blue regions, reflecting uncertainties in the wall loss coefficient (i.e., 0.17 or $0.09 \mathrm{~h}^{-1}$ ). The parameterizations of upper and lower sides of the shaded region are given in Table 2. The wall-loss-corrected yields, representing our best-estimate yields, were 1.3 to 1.6 times larger than the uncorrected yields.

A comparison of our best-estimate yields to literature results for the dark ozonolysis of $\alpha$-pinene is shown in Fig. 4. Panels A1 and A2 show the data as reported by the original authors, with the exception of the data of Gao et al. (2004b) and Song et al. (2007) which we adjusted to an SOA particle density of $1.0 \mathrm{~g} \mathrm{~cm}^{-3}$. As seen in Table 3 , experiments in the literature were conducted across a wide temperature range, affecting the measured yield. Therefore, we adjusted the literature data to $298 \mathrm{~K}$ (Panels B1 and B2), using a temperature correction of $1.6 \%$ per $\mathrm{K}$, as recommended by Pathak et al. (2007a). In addition, Table 3 illustrates that there were other differences among the studies including relative humidity, presence and composition of the seed particles, presence and identity of the $\mathrm{OH}$ radical scavenger, and ozone concentration. We attempted no normalizations for these differences.

As seen in Fig. 4, the yields reported by us for intermediate mass loadings $\left(>5 \mu \mathrm{g} \mathrm{m}^{-3}\right)$ are in agreement with some of the latest studies but up to 1.8 to 2.0 times larger compared to some of the other studies. Chan and Seinfeld (2007) showed that the parameterization of Griffin et al. (1999b) can be brought into agreement with our observations for an assumed enthalpy of vaporization of $100 \mathrm{~kJ} \mathrm{~mole}{ }^{-1}$ ), corresponding to a temperature correction much greater than the recommendation of $1.6 \%$ per $\mathrm{K}$ by Pathak et al. (2007a). At lower mass loadings $\left(<5 \mu \mathrm{g} \mathrm{m}^{-3}\right)$, for which only Pathak et al. (2007a) provide data for comparison, our best-estimate yields are offset by approximately +0.07 . The differences between our results and those in the literature are outside the probable range of instrumental errors and analysis uncertainties, as reflected by the uncertainty bars shown in Fig. 3. Observations of greater yields in our study and some of the other latest studies could potentially reduce the differences between the predictions of chemical transport models (which have been informed by the lower yields of earlier laboratory measurements) and ambient observations (de Gouw et al., 2005; Heald et al., 2005; Takegawa et al., 2006; Volkamer et al., 2006). For the rest of the data analysis, we focus on our results at the lower mass loadings $\left(<5 \mu \mathrm{g} \mathrm{m}^{-3}\right)$ most relevant to atmospheric conditions. A goal is to explain why the yields were higher for our measurements compared to 
those reported by Pathak et al. (2007a) for experimental approaches similar in many aspects. The different experimental parameters (e.g., relative humidity, $\mathrm{OH}$ scavenger, and so forth, as presented in Table 3) have no discernable regression that explains the variability in yield. For the remainder of this paper, we examine and eventually rule out possible experimental artifacts. Under the assumption that all data in this study and in the literature are correct, the conclusion then must be that unidentified factors affecting yield exist that the scientific community is not yet knowledgeable about.

As a first check against artifacts, to validate the experimental data and to test the possibility of background particle production in the chamber, we carried out a series of control experiments in the continuous-flow mode, as outlined in Table 4. With the main air flow active and in the presence of ozone (control 1), particle number concentrations remained below $5 \mathrm{~cm}^{-3}$ by CPC detection and particle mass loading remained below the detection limit $\left(0.02 \mu \mathrm{g} \mathrm{m}^{-3}\right)$ of the AMS (DeCarlo et al., 2006). Addition of ammonium sulfate seed particles to the inflow (control 2) did not alter the null organic signal of the AMS. These controls indicated that no condensable organic vapors were present in the air supply of the Aadco generator or in the set-up for RH control. These controls also demonstrated both that no condensable organic vapors were released from the chamber walls and that no organic particles (possibly released as impurities from the water bubbler or the ammonium sulfate seed solution) reached the chamber. Experiments with all reactive species present except ozone (control 3) demonstrated that no organic particle growth occurred in the absence of ozone, thus ruling out particle contamination from the butanol or $\alpha$-pinene. Experiments without $\alpha$-pinene but with butanol and ozone (control 4) also showed no organic particle growth, suggesting that reactive impurities were not present in the 1-butanol solution. In summary, organic particle growth was detected by the AMS and the SMPS only when $\alpha$-pinene and ozone were simultaneously introduced into the chamber.

One issue differentiating our experimental approach from that in other studies was the use of the AMS in the former and the SMPS in the latter for determining yield. The SMPS measured volume loadings that were converted to mass loadings ( $\left.\Delta M_{\text {SMPS }}\right)$ using the organic particle density, typically normalized to $1.0 \mathrm{~g} \mathrm{~cm}^{-3}$. In contrast, the AMS provided a measure of $\Delta M$ subject to the accuracy of the calibration. To investigate any possible bias in $\Delta M_{\mathrm{AMS}}$, in particular its equivalency to $\Delta M_{\mathrm{SMPS}}$, we also made measurements of $\Delta M_{\text {SMPS }}$. A scatter plot of $\Delta M_{\text {AMS }}$ with $\Delta M_{\text {SMPS }}$ is shown in Fig. 5 for 0.5 to $6 \mu \mathrm{g} \mathrm{m}^{-3}$. The clustering of the points around the $1: 1$ line shows that the two quantities agreed well. The analysis in Fig. 5 is limited to low SOA mass loadings $\left(<10 \mu \mathrm{g} \mathrm{m}^{-3}\right)$. For higher loadings, the large-diameter tail of the size distribution extended beyond the 500-nm limit of the SMPS, preventing accurate measurements of $\Delta M_{\text {SMPS. }}$. The good correlation in Fig. 5 also supports the use of an AMS collection efficiency of unity and the

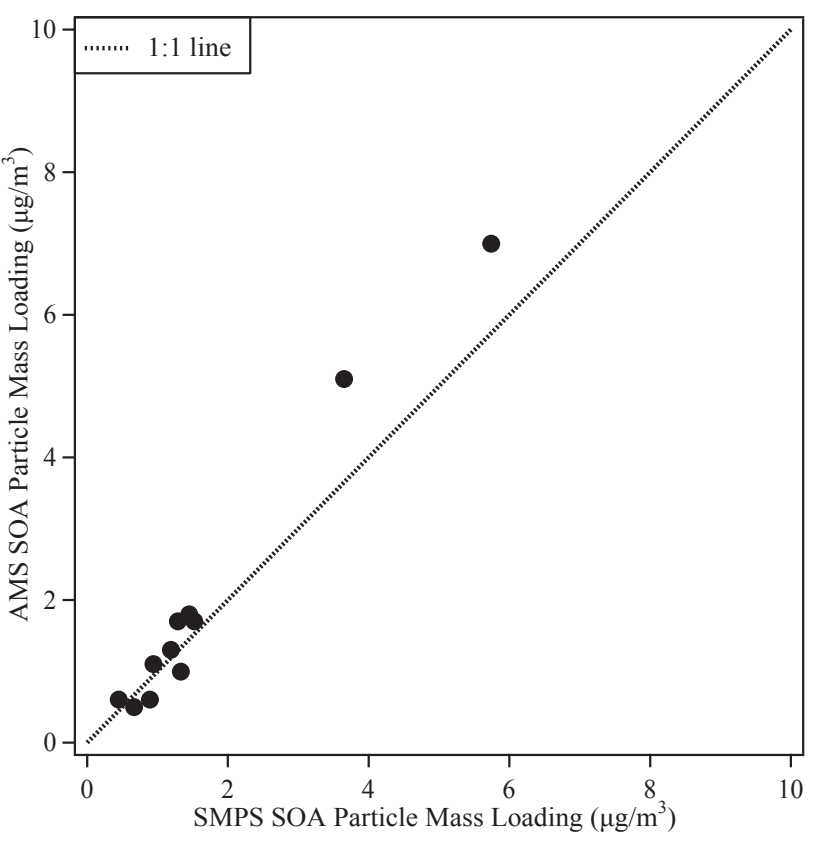

Fig. 5. SOA particle mass loadings measured by the AMS compared to those determined from the SMPS data. Volume loadings measured by the SMPS are multiplied by the measured densities to determine mass loadings. See equations in the Appendix.

assumption of spherical particles. The density of the organic material, which was needed for the conversion of volume to mass in the analysis of the SMPS data, was calculated at each mass loading using the approach of DeCarlo et al. (2004) and Katrib et al. (2005), as described in the Appendix. The organic densities (Table 1) decreased with increasing organic loading, implying a change in chemical composition that is consistent with the greater oxygen content observed in the mass spectra. A detailed analysis of this topic, as well as the associated mass spectra, will be the subject of a future report. In summary, the yields we report in Figs. 3 and 4 are redundantly supported by the AMS and SMPS data, at least for $<10 \mu \mathrm{g} \mathrm{m}^{-3}$.

The yields for most of the literature experiments shown in Fig. 4 were obtained using 2-butanol as an $\mathrm{OH}$ scavenger (cf. Table 3), compared to 1-butanol used by us. To investigate the possibility that this difference might significantly affect yield, we conducted a batch-mode experiment using 2-butanol as the scavenger. As seen in Fig. 3, yields obtained when using 2-butanol (orange triangles) were similar as when using 1-butanol (green triangles). The major products of the $\mathrm{OH}$-initiated oxidation of 1-butanol are butanal, propanal, ethanal, and formaldehyde (Cavalli et al., 2002), compared to 2-butanone for the oxidation of 2-butanol (Chew and Atkinson, 1996). The high vapor pressures of these molecules suggest that they are too volatile to partition into the particle phase (Barsanti and Pankow, 2004), although reactive uptake of aldehydes may be important under some 
Table 4. Summary of the results of control experiments concerning SOA production in the chamber. The criterion for a positive result was detection of an organic particle loading above the detection limit $\left(0.022 \mu \mathrm{g} \mathrm{m}^{-3}\right)$ of the HR-ToF-AMS.

\begin{tabular}{|c|c|c|c|c|c|}
\hline \multirow{2}{*}{ Description } & \multicolumn{4}{|c|}{ Variables } & \multirow{2}{*}{$\begin{array}{c}\text { Observation } \\
\text { SOA Formation }\end{array}$} \\
\hline & $\left(\mathrm{NH}_{4}\right)_{2} \mathrm{SO}_{4}$ Seed & Ozone (>300 ppbv) & 1-butanol (>1 ppmv) & $\alpha$-pinene & \\
\hline Control 1: Ozone Only & No & Yes & No & No & No \\
\hline Control 2: Seed and Ozone Only & Yes & Yes & No & No & No \\
\hline Control 3: No Ozone & Yes & No & Yes & Yes & No \\
\hline Control 4: No $\alpha$-pinene & Yes & Yes & Yes & No & No \\
\hline Experiment & Yes & Yes & Yes & Yes & Yes \\
\hline
\end{tabular}

conditions (Jang and Kamens, 2001; Jang et al., 2002)

A potential factor affecting yields in the different experiments is that the gas-phase chemistry of the dark ozonolysis of $\alpha$-pinene could change among different experimental configurations and conditions, principally because of secondorder reactions of peroxy radicals. To quantitatively investigate this possibility, we simulated $\alpha$-pinene ozonolysis in the presence of 1-butanol using the Master Chemical Mechanism (MCM) (version 3.1) (Saunders et al., 2003). The time evolution of species, revealing the higher peak concentration of peroxy radicals for batch mode because of the greater rates of $\alpha$-pinene oxidation, is shown in Fig. 6. Although the model omits SOA particle growth and gas-phase species scavenging to the walls and although the MCM is incomplete as indicated by the absence of species of sufficiently low volatility to form SOA (Jenkin, 2004), the relative concentrations of species across the different experimental modes (Table 5) show that the composition of the predicted gasphase products should be similar in the continuous-flow and batch modes for ozone concentrations of 300 ppbv. Among pinonic acid, pinaldehyde, norpinonaldehyde, pinic acid, and hydroxypinonic acid, the greatest difference is $-10 \%$ for the short-time batch mode and $+1 \%$ for the long-time batch mode compared to the continuous-flow mode. The mass yield of particles should also therefore be similar, at least so long as partitioning theory for gas-phase products governs particle growth. Differences among modes do, however, increase for higher ozone concentrations, as indicated for short-time high-ozone batch mode. Differences are greatest for peroxy radicals and for hydroperoxide species. As an experimental test of the possible importance of the ozone concentration, we carried out two experiments at $50 \mathrm{ppbv}$. Within error, yields for $50 \mathrm{ppbv}$ ozone (blue circles; Fig. 3) lie along the same curve as those determined for $300 \mathrm{ppbv}$ ozone (red circles). Nevertheless, we did not experimentally test the higher ozone concentrations used in Pathak et al. (2007a) ( $\geq 750 \mathrm{ppb}$ ), so the hypothesis remains open that at least some of the differences in yield at low mass loadings are possibly attributable to differences in gas-phase chemistry.

Another hypothesis, also considered but ruled out, to ex- plain the higher yields observed by us was that semivolatile mass might accumulate on the walls prior to the measurements and subsequently might bleed off the walls during the measurements, condense onto the particles, and thereby lead to systematically high yields. As a practical matter, we cleaned the walls before each measurement so that, if the walls did not come to equilibrium, they were a sink of material, which would have the effect of understating rather than overstating yields. In addition, we observed that the particle loadings reached steady-state within approximately $24 \mathrm{~h}$ of any perturbation to the chamber and remained stable for week-long time periods.

\section{Conclusions}

The yield of particle mass in secondary organic aerosol was measured for the dark ozonolysis of 0.3-22.8 ppbv of reacted $\alpha$-pinene at $298 \mathrm{~K}$ and $40 \% \mathrm{RH}$. The yields determined by two independent instruments, namely an AMS and an SMPS, agreed well. The yields for low loadings of $<5 \mu \mathrm{g} \mathrm{m}^{-3}$ had an offset of approximately +0.07 from those reported by Pathak et al. (2007a), which was the only other study to conduct experiments at loadings typical of the atmosphere (Fig. 4, panel B). We investigated several possible artifacts and sources of error that reasonably could have influenced yield and explained the offset yield of +0.07 . We concluded, however, that the higher yields we observed can be explained by none of the considered possibilities. Under the assumption that both our data and the literature data are correct, we further concluded that there are poorly understood or even unknown factors influencing particle yield in chamber SOA experiments. Some of these same factors may contribute to the variance of 1.8 to 2.0 in yield among 11 studies carried out for intermediate loadings ( 5 to $40 \mu \mathrm{g} \mathrm{m}^{-3}$ ) (Fig. 4, panel B).

The processes occurring within continuous-flow and batch-mode chambers are complex, and yield represents the fractional partitioning of molecules between the gas and particle phases of an aerosol. This partitioning depends on the identity of the molecules and hence the chemistry that takes place to form those molecules. In addition to gas-phase 

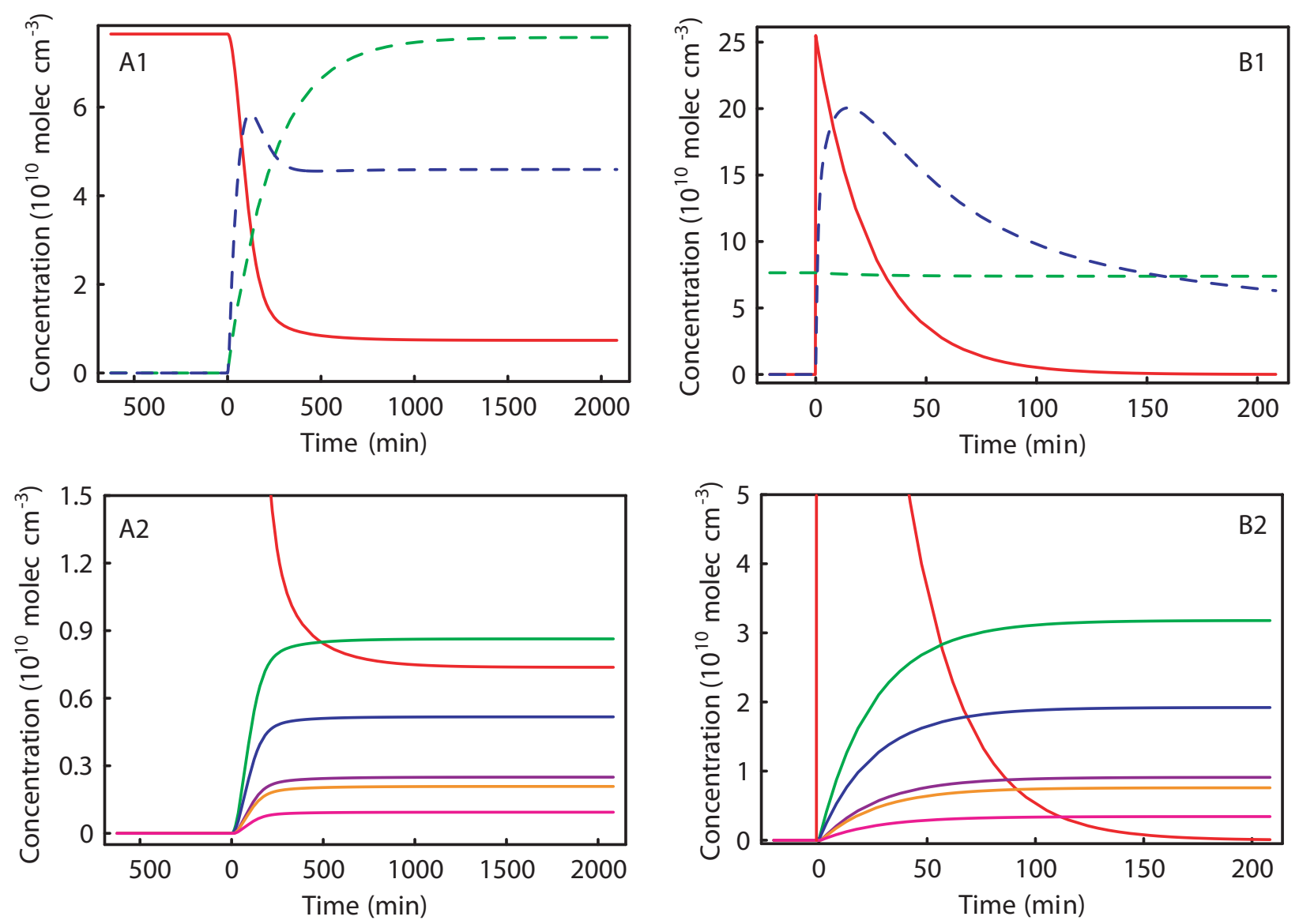

Fig. 6. Model simulations using the Master Chemical Mechanism (MCM), V3.1 (Saunders et al., 2003) for (A) continuous-flow and (B) batch-mode experiments. The model predicted gas-phase products but omitted SOA production and scavenging of species to the walls. The environmental chamber was modeled as a continuously stirred tank reactor. Legend: $\alpha$-pinene (red), ozone (dashed green, $\times 10^{-2}$ ), peroxy radicals, (dashed blue, $\times 10$ ), pinonic acid (green), pinaldehyde (blue), norpinonaldehyde (purple), pinic acid (orange), and hydroxypinonic acid (magenta). Conditions: (1) continuous-flow mode, $3 \mathrm{ppb} \alpha$-pinene prior to ozonolysis, $300 \mathrm{ppb}$ ozone, $3 \mathrm{ppm} 1$-butanol, $40 \% \mathrm{RH}, 25^{\circ} \mathrm{C}$, and residence time of $4.0 \mathrm{~h}$; (2) batch mode, $10 \mathrm{ppb} \alpha$-pinene prior to ozonolysis, $300 \mathrm{ppb}$ ozone, $10 \mathrm{ppm} 1$-butanol, $40 \% \mathrm{RH}$, and $25^{\circ} \mathrm{C}$.

chemistry inside the chamber, partitioning of the product molecules occurs among the surfaces of the walls, particles deposited on the walls, and aerosol particles. Possible reactive chemistry occurs on the walls or in the particles. Even so, for the continuous-flow chamber at steady-state, high confidence is possible regarding the lower limit of $Y^{s s}$ (i.e., $Y^{s s}=\Delta M^{s s} / \Delta H C^{s s}$ ). The particle mass flow out of the chamber (setting a lower limit on $\Delta M^{s s}$ ) is accurately measured. The amount of reacted $\alpha$-pinene $\left(\Delta H C^{s s}\right)$ is also accurately measured (e.g., the PTR-MS measurements agreed well with the value calculated from the known reaction rates). High confidence in the lower limit of $Y^{s s}$ therefore follows. Moreover, we can have this high confidence for low concentrations of reacted hydrocarbon and particle mass loading because of signal integration in steady-state.

Further work and hypotheses are required to understand the factors leading to the differences observed between our results and those reported in the literature. Several factors known to influence yield, such as ammonia concentration, liquid or solid seed-particle phase, and seed-particle acidity, were similar among the group of experiments tabulated in Table 3 and so these factors would not appear to be the explanation. Pathak et al. (2007a) and Kroll et al. (2007), however, highlighted several other factors that can affect yields, including the direct loss of semivolatile species to the walls of the chamber. The extent of interactions with the walls should depend on the particulars of the chamber geometry and its operation, which differed among the various experiments of Table 3. The interactions with the walls would be most important for the lowest quantities of reacted VOC because only the lowest volatility molecules can contribute to particle growth. As an upper-limit estimate of the volatility we can infer from our results, for the assumption of a single species having a molecular weight of $200 \mathrm{~g} \mathrm{~mol}^{-1}$ contributing to the organic mass at $0.15 \mathrm{\mu g} \mathrm{m}^{-3}$, the corresponding vapor pressure is $1.4 \times 10^{-8}$ Torr at $298 \mathrm{~K}$. This vapor pressure is twenty 
Table 5. Relative concentrations (given as a molar percentage of the total gas-phase product concentration) of the predicted gas-phase product yields using the Master Chemical Mechanism (MCM), V3.1 (Saunders et al., 2003) for the dark ozonolysis of $\alpha$-pinene. Results are shown for simulations of continuous-flow, short-time batch, short-time batch under high ozone, and long-time batch modes of chamber operation. The short-time column shows the relative gas-phase concentrations $15 \mathrm{~min}$ after the start of the reaction, which is the time point of maximum of [ROO] (cf. Fig. 6). The long-time column corresponds to $2000 \mathrm{~min}$ after the start of the reaction. The second column for the batch-mode results shows the ratio of the relative concentrations to the continuous-flow results. Products shown account for $95 \%$ of the $\mathrm{C}_{5}$ and greater products, excluding the remaining $\alpha$-pinene. Conditions of the simulations are given in the caption of Fig. 6 . The short-time batch-mode high-ozone simulation was run at $1500 \mathrm{ppbv}$ ozone. The model predicts gas-phase products and omits SOA production and scavenging of species to the walls. Products are labeled as the SMILES strings of the MCM.

\begin{tabular}{|c|c|c|c|c|c|c|c|}
\hline \multirow{3}{*}{$\begin{array}{l}\text { Product } \\
\mathrm{C} 107 \mathrm{OOH}\end{array}$} & \multicolumn{7}{|c|}{ Mode } \\
\hline & \multirow{2}{*}{$\begin{array}{c}\text { Continuous Flow } \\
18.7 \%\end{array}$} & \multicolumn{2}{|c|}{ Short-Time Batch } & \multicolumn{2}{|c|}{ Long-Time Batch } & \multicolumn{2}{|c|}{$\begin{array}{c}\text { Short-Time Batch } \\
\text { High Ozone }\end{array}$} \\
\hline & & $19.9 \%$ & 1.06 & $18.5 \%$ & 0.99 & $18.0 \%$ & 0.96 \\
\hline PINONIC & $13.0 \%$ & $13.1 \%$ & 1.01 & $13.1 \%$ & 1.00 & $12.8 \%$ & 0.98 \\
\hline $\mathrm{C} 97 \mathrm{OOH}$ & $9.6 \%$ & $6.8 \%$ & 0.71 & $9.8 \%$ & 1.02 & $7.4 \%$ & 0.77 \\
\hline $\mathrm{C} 108 \mathrm{OOH}$ & $8.1 \%$ & $3.5 \%$ & 0.43 & $9.1 \%$ & 1.13 & $5.1 \%$ & 0.64 \\
\hline PINAL & $7.8 \%$ & $8.0 \%$ & 1.02 & $7.9 \%$ & 1.01 & $8.2 \%$ & 1.05 \\
\hline $\mathrm{C} 89 \mathrm{CO} 2 \mathrm{H}$ & $5.7 \%$ & $5.2 \%$ & 0.93 & $5.6 \%$ & 0.99 & $5.3 \%$ & 0.94 \\
\hline $\mathrm{C} 107 \mathrm{OH}$ & $4.0 \%$ & $2.5 \%$ & 0.63 & $4.8 \%$ & 1.19 & $3.9 \%$ & 0.96 \\
\hline $\mathrm{C} 96 \mathrm{OH}$ & $3.8 \%$ & $3.4 \%$ & 0.90 & $3.7 \%$ & 0.99 & $3.5 \%$ & 0.94 \\
\hline NORPINAL & $3.8 \%$ & $3.4 \%$ & 0.90 & $3.7 \%$ & 0.99 & $3.6 \%$ & 0.94 \\
\hline PINIC & $3.1 \%$ & $2.9 \%$ & 0.91 & $3.1 \%$ & 0.99 & $3.0 \%$ & 0.94 \\
\hline $\mathrm{C} 9210 \mathrm{OH}$ & $2.5 \%$ & $1.6 \%$ & 0.63 & $2.6 \%$ & 1.01 & $1.8 \%$ & 0.73 \\
\hline $\mathrm{C} 107 \mathrm{O} 2$ & $2.2 \%$ & $6.4 \%$ & 2.86 & & & $2.8 \%$ & 1.26 \\
\hline $\mathrm{C} 8900 \mathrm{OH}$ & $2.2 \%$ & $1.6 \%$ & 0.72 & $2.3 \%$ & 1.02 & $1.7 \%$ & 0.77 \\
\hline $\mathrm{C} 10900 \mathrm{OH}$ & $1.7 \%$ & $3.5 \%$ & 2.07 & $2.2 \%$ & 1.29 & $2.6 \%$ & 1.56 \\
\hline $\mathrm{C} 812 \mathrm{OOH}$ & $2.1 \%$ & $1.7 \%$ & 0.79 & $1.9 \%$ & 0.92 & $1.7 \%$ & 0.81 \\
\hline $\mathrm{C} 96 \mathrm{OOH}$ & $1.8 \%$ & $3.5 \%$ & 1.91 & $2.2 \%$ & 1.23 & $2.7 \%$ & 1.48 \\
\hline HOPINONIC & $1.4 \%$ & $1.3 \%$ & 0.92 & $1.4 \%$ & 0.99 & $1.3 \%$ & 0.94 \\
\hline $\mathrm{C} 109 \mathrm{CO}$ & $1.3 \%$ & $1.2 \%$ & 0.93 & $1.3 \%$ & 0.99 & $1.3 \%$ & 1.00 \\
\hline $\mathrm{C} 109 \mathrm{OH}$ & $1.3 \%$ & $1.2 \%$ & 0.93 & $1.3 \%$ & 0.99 & $1.2 \%$ & 0.93 \\
\hline $\mathrm{C} 97 \mathrm{O} 2$ & $1.2 \%$ & $3.1 \%$ & 2.67 & & & $2.7 \%$ & 2.31 \\
\hline $\mathrm{C} 811 \mathrm{OH}$ & $1.3 \%$ & $0.9 \%$ & 0.69 & $1.3 \%$ & 1.00 & $0.7 \%$ & 0.55 \\
\hline $\mathrm{C} 721 \mathrm{CHO}$ & $1.3 \%$ & $1.1 \%$ & 0.83 & $1.3 \%$ & 1.00 & $1.2 \%$ & 0.92 \\
\hline $\mathrm{C} 108 \mathrm{O} 2$ & $1.0 \%$ & $2.3 \%$ & 2.34 & & & $3.5 \%$ & 3.65 \\
\hline $\mathrm{C} 813 \mathrm{OOH}$ & $0.9 \%$ & & & $1.1 \%$ & 1.17 & $0.6 \%$ & 0.58 \\
\hline $\mathrm{C} 811 \mathrm{OH}$ & & $1.1 \%$ & & & & $0.5 \%$ & \\
\hline C921O2 & & $0.8 \%$ & & & & $0.8 \%$ & \\
\hline $\mathrm{C} 812 \mathrm{O} 2$ & & $0.8 \%$ & & & & $0.4 \%$ & \\
\hline $\mathrm{CO} 235 \mathrm{C} 6 \mathrm{CHO}$ & & & & $1.1 \%$ & & & \\
\hline $\mathrm{C} 108 \mathrm{OH}$ & & & & $0.6 \%$ & & & \\
\hline APINAOOH & & & & & & $1.0 \%$ & \\
\hline $\mathrm{C} 89 \mathrm{O} 2$ & & & & & & $0.6 \%$ & \\
\hline
\end{tabular}

times lower than that of pinic acid $\left(32 \times 10^{-8}\right.$ Torr) (Bilde and Pandis, 2001), which is a $\mathrm{C}_{9}$ dicarboxylic acid identified as a product of $\alpha$-pinene ozonolysis (Yu et al., 1999) and is possibly the least-volatile monomer species. Jenkin (2004) modeled SOA formation during $\alpha$-pinene ozonolysis from the gas-phase mechanism embedded in the Master Chemical Mechanism and had to artificially reduce the volatility of the products by a factor of 100 to explain particle growth. Our observations of significant particle mass at low concentrations of reacted $\alpha$-pinene, together with the vapor pressures of the known momomeric species (Bilde and Pandis, 2001) and the study of Jenkin (2004), suggest that oligomeric or highly oxygenated material of low volatility is a key component of SOA particle mass at low loadings. Experimental configurations and interactions with walls may then be crucial to understanding differences among yields. The related follow-on inference is that the higher yields measured in this study would thus be explained by less interaction with the walls and therefore could be closer to the yields expected under atmospheric conditions. 
The absence of a conclusive explanation notwithstanding, the increased yields observed in our experiments, especially for low loadings, are potentially important for reconciling the differences between the higher organic particle concentrations observed in many geographic locations and the lower concentrations presently predicted by chemical transport models, which are based in large part on the lower yields reported in earlier literature.

\section{Appendix A}

\section{Measurement of mass loading}

The AMS directly measures organic particle mass loading $C_{\text {particle }}^{s s}$, which we label $C_{\text {particle }}^{s s, \text { GMS }}$. Given the absence of initial organic loading, we have: $\Delta M_{\mathrm{AMS}}^{s s}=C_{\text {particle }}^{s s, \mathrm{AMS}} \cdot C_{\text {particle }}^{s s, \mathrm{AMS}}$ was typically calculated by averaging between 4 and $12 \mathrm{~h}$ of the MS-mode data. The AMS ionization efficiency was calibrated with monodisperse ammonium nitrate particles. Signal intensities were converted to nitrate-equivalent mass loading, as described in the literature (Jayne et al., 2000; Allan et al., 2003; Jimenez et al., 2003). Inorganic species were separated from organic species based on reproducible fragmentation patterns obtained in laboratory calibrations (Allan et al., 2003; Jimenez et al., 2003). Corrections for gas-phase species fragmenting at $\mathrm{m} / \mathrm{z} 29,40$, and 44 were made using the P-ToF mode of the AMS for each individual experiment (Jayne et al., 2000). Based on the results of a highloading experiment, the particle-phase signal intensity at $\mathrm{m} / \mathrm{z}$ 28 (from $\mathrm{CO}^{+}$) was calculated as 1.075 times that of the particle-phase $\mathrm{CO}_{2}^{+}$signal at $m / z, 44$ (from $\mathrm{CO}_{2}^{+}$). This value was similar to that of 1.15 reported by DeCarlo et al. (2006).

The AMS lens transmits particles of vacuum aerodynamic diameters between 70 and $500 \mathrm{~nm}$ with nearly $100 \%$ efficiency and shows substantial transmission of particles with diameters between 500-2000 nm (Jayne et al., 2000). For experiments described herein, the vacuum-aerodynamic size distribution was almost entirely within the 70 to $500 \mathrm{~nm}$ range. Particle bounce off the heater and loss of particles as a result of inefficient focusing were assumed negligible, and a net collection efficiency of unity was therefore used in the calculations (Huffman et al., 2005). Agreement between the AMS and SMPS data shown in Fig. 5 suggested that this assumption was valid.

Compared to the direct mass measurements of the AMS, the SMPS data directly measured the volume concentration of the organic material. The mass loading $C_{\text {particle }}^{s s, \text { SMPS }}$ was then obtained using the organic-phase density. We omitted any hygroscopic growth of the particles $(40 \% \mathrm{RH})$ and assumed that the particles were spherical.

The particle size distributions measured by the SMPS for the steady-state aerosol and the initial seed particles $\left(n^{s s}\left(D_{p}\right)\right.$ and $n^{\text {seed }}\left(D_{p}\right)$, respectively) were used to calculate the organic particle mass concentration, as follows:

$$
\begin{aligned}
& \Delta M_{\mathrm{SMPS}}^{s s}=C_{\text {particle }}^{s s, \text { SMPS }}= \\
& \rho_{\mathrm{SOA}} \frac{\pi}{6} \int_{D_{p}^{\min }}^{D_{p}^{\max }}\left(n^{s s}\left(D_{p}\right)-n^{\text {seed }}\left(D_{p}\right)\right) D_{p}^{3} d D_{p}
\end{aligned}
$$

The organic-phase density $\left(\rho_{\mathrm{SOA}}\right)$ was obtained from the AMS-measured vacuum aerodynamic diameter in conjunction with SMPS measurements of mobility diameter, including a volume-weighted accounting of the ammonium sulfate seed (DeCarlo et al., 2004; Katrib et al., 2005) (Fig. S1, http://www.atmos-chem-phys.net/8/2073/ 2008/acp-8-2073-2008-supplement.pdf).

\section{Appendix B}

\section{Two-product model}

The reacted hydrocarbon mass is assumed to form $j$ product classes of respective mass yields $\alpha_{j}$ (Pankow, 1994a, b; Odum et al., 1996). For each product class, a volatility coefficient $K_{j}$ quantifies the partitioning between the particle and gas phases. Yield data are then parameterized according to the following equation:

$$
Y=\sum_{i} \frac{\alpha_{j} K_{j} C_{\text {particle }}^{s s}}{1+K_{j} C_{\text {particle }}^{s s}}
$$

Most typically, two product classes are sufficient to describe the yield data.

\section{Appendix C}

\section{Basis-set model}

The volatility of the product classes is prescribed in decadal units of $10^{-j}$, where $10^{-j}$ corresponds to $1 / K_{j}$ of the twoproduct model and is often denoted by $C_{j}^{*}$ (Donahue et al., 2005). In this case, we obtain:

$Y=\sum_{j} \alpha_{j}\left(1+\frac{10^{-j}}{C_{\text {particle }}^{s s}}\right)^{-1}=\sum_{j} \alpha_{j}\left(1+\frac{C_{j}^{*}}{C_{\text {particle }}^{s s}}\right)^{-1}$

Four decadal units of volatility are typically sufficient to describe the yield data.

Acknowledgements. This material is based upon work supported by the National Science Foundation under Grant No. ATM-0513463. Q. Chen acknowledges support from the NASA ESS fellowship program. S. M. King acknowledges support from the EPA STAR fellowship program. T. Rosenoern acknowledges support from the Danish Agency for Science Technology and Innovation under Grant No. 272-06-0318. The authors thank N. Donahue, S. Pandis, 
J. Seinfeld, and S. Ng for helpful comments and A. Chan for providing us with the new measurements described in the ACPD comment.

Edited by: R. Cohen

\section{References}

Allan, J. D., Jimenez, J. L., Williams, P. I., Alfarra, M. R., Bower, K. N., Jayne, J. T., Coe, H., and Worsnop, D. R.: Quantitative sampling using an aerodyne aerosol mass spectrometer -1 . Techniques of data interpretation and error analysis, J. Geophys. Res., 108, 4090, doi:10.1029/2002JD002359, 2003.

Andreae, M. O. and Crutzen, P. J.: Atmospheric aerosols: Biogeochemical sources and role in atmopsheric chemistry, Science, 276, 1052-1058, 1997.

Barsanti, K. C. and Pankow, J. F.: Thermodynamics of the formation of atmospheric organic particulate matter by accretion reactions - part 1: Aldehydes and ketones, Atmos. Environ., 38, 4371-4382, 2004.

Bilde, M. and Pandis, S. N.: Evaporation rates and vapor pressures of individual aerosol species formed in the atmospheric oxidation of alpha- and beta-pinene, Environ. Sci. Technol., 35, 33443349, 2001.

Blando, J. D. and Turpin, B. J.: Secondary organic aerosol formation in cloud and fog droplets: A literature evaluation of plausibility, Atmos. Environ., 34, 1623-1632, 2000.

Cavalli, F., Geiger, H., Barnes, I., and Becker, K. H.: FTIR kinetic, product, and modeling study of the $\mathrm{OH}$-initiated oxidation of 1butanol in air, Environ. Sci. Technol., 36, 1263-1270, 2002.

Chan, A. and Seinfeld, J.H.: Interactive Comment on "Particle mass yield in secondary organic aerosol formed by the dark ozonolysis of $\alpha$-pinene" by J. E. Shilling et al., Atmos. Chem. Phys. Discuss., 7, S7725S7726, 2007.

Chen, J., Griffin, R. J., Grini, A., and Tulet, P.: Modeling secondary organic aerosol formation through cloud processing of organic compounds, Atmos. Chem. Phys. Discuss., 7, 8951-8922, 2007, http://www.atmos-chem-phys-discuss.net/7/8951/2007/.

Chew, A. A. and Atkinson, R.: OH radical formation yields from the gas-phase reactions of $\mathrm{O}_{3}$ with alkenes and monoterpenes, $\mathrm{J}$. Geophys. Res., 101, 28 649-28 653, 1996.

Chung, S. H. and Seinfeld, J. H.: Global distribution and climate forcing of carbonaceous aerosols, J. Geophys. Res., 107, 4407, doi:10.1029/2001JD001397, 2002.

Cocker, D. R., Clegg, S. L., Flagan, R. C., and Seinfeld, J. H.: The effect of water on gas-particle partitioning of secondary organic aerosol. Part I: $\alpha$-pinene/ozone system, Atmos. Environ., 35, 6049-6072, 2001.

de Gouw, J. A., Middlebrook, A. M., Warneke, C., Goldan, P. D., Kuster, W. C., Roberts, J. M., Fehsenfeld, F. C., Worsnop, D. R., Canagaratna, M. R., Pszenny, A. A. P., Keene, W. C., Marchewka, M., Bertman, S. B., and Bates, T. S.: Budget of organic carbon in a polluted atmosphere: Results from the New England air quality study in 2002, J. Geophys. Res., 110, D16305, doi:10.1029/2004JD005623, 2005.

DeCarlo, P., Slowik, J., Worsnop, D., Davidovits, P., and Jimenez, J.: Particle morphology and density characterization by com- bined mobility and aerodynamic diameter measurements. Part 1: Theory, Aerosol Sci. Technol., 38, 1185-1205, 2004.

DeCarlo, P. F., Kimmel, J. R., Trimborn, A., Jayne, J. T., Aiken, A., Gonin, M., Fuhrer, K., Horvath, T., Docherty, K. S., Worsnop, D. R., and Jimenez, J. L.: A field-deployable high-resolution timeof-flight aerosol mass spectrometer, Anal. Chem., 78, 82818289, 2006.

Dockery, D. W., Pope, C. A., Xu, X. P., Spengler, J. D., Ware, J. H., Fay, M. E., Ferris, B. G., and Speizer, F. E.: An association between air-pollution and mortality in 6 United-States cities, N. Engl. J. Med., 329, 1753-1759, 1993.

Donahue, N. M., Hartz, K. E. H., Chuong, B., Presto, A. A., Stanier, C. O., Rosenoern, T., Robinson, A. L., and Pandis, S. N.: Critical factors determining the variation in SOA yields from terpene ozonolysis: A combined experimental and computational study, Faraday Discuss., 130, 295-309, 2005.

Gao, S., Keywood, M., Ng, N. L., Surratt, J., Varutbangkul, V., Bahreini, R., Flagan, R. C., and Seinfeld, J. H.: Low-molecularweight and oligomeric components in secondary organic aerosol from the ozonolysis of cycloalkenes and alpha-pinene, J. Phys. Chem. A, 108, 10 147-10 164, 2004a.

Gao, S., Ng, N. L., Keywood, M., Varutbangkul, V., Bahreini, R., Nenes, A., He, J. W., Yoo, K. Y., Beauchamp, J. L., Hodyss, R. P., Flagan, R. C., and Seinfeld, J. H.: Particle phase acidity and oligomer formation in secondary organic aerosol, Environ. Sci. Technol., 38, 6582-6589, 2004b.

Griffin, R. J., Cocker, D. R., Seinfeld, J. H., and Dabdub, D.: Estimate of global atmospheric organic aerosol from oxidation of biogenic hydrocarbons, Geophys. Res. Lett., 26, 2721-2724, 1999a.

Griffin, R. J., Cocker, D. R., Flagan, R. C., and Seinfeld, J. H.: Organic aerosol formation from the oxidation of biogenic hydrocarbons, J. Geophys. Res., 104, 3555-3567, 1999b.

Gross, D. S., Galli, M. E., Kalberer, M., Prevot, A. S., Dommen, J., Alfarra, M. R., Duplissy, J., Gaeggeler, K., Gascho, A., Metxger, A., and Baltensperger, U.: Real-time measurement of oligomeric species in secondary organic aerosol with the aerosol time-offlight mass spectrometer, Anal. Chem., 78, 2130-2137, 2006.

Heald, C. L., Jacob, D. J., Park, R. J., Russell, L. M., Huebert, B. J., Seinfeld, J. H., Liao, H., and Weber, R. J.: A large organic aerosol source in the free troposphere missing from current models, Geophys. Res. Lett., 32, L18809, doi:10.1029/2005GL023831, 2005.

Heaton, K. J., Dreyfus, M. A., Wang, S., and Johnston, M. V.: Oligomers in the early stage of biogenic secondary organic aerosol formation and growth, Environ. Sci. Technol., 41, 61296136, 2007.

Hoffmann, T., Odum, J. R., Bowman, F., Collins, D., Klockow, D., Flagan, R. C., and Seinfeld, J. H.: Formation of organic aerosols from the oxidation of biogenic hydrocarbons, J. Atmos. Chem., 26, 189-222, 1997.

Huffman, J. A., Jayne, J. T., Drewnick, F., Aiken, A. C., Onasch, T. B., Worsnop, D. R., and Jimenez, J. L.: Design, modeling, optimization and experimental tests of a particle beam width probe for the aerodyne aerosol mass spectrometer, Aerosol Sci. Technol., 39, 1143-1163, 2005.

Iinuma, Y., Boge, O., Miao, Y., Sierau, B., Gnauk, T., and Hermann, H.: Laboratory studies on secondary organic aerosol formation from terpenes, Faraday Discuss., 130, 279-294, 2005. 
Jang, M. S. and Kamens, R. M.: Atmospheric secondary aerosol formation by heterogeneous reactions of aldehydes in the presence of a sulfuric acid aerosol catalyst, Environ. Sci. Technol., 35, 4758-4766, 2001.

Jang, M. S., Czoschke, N. M., Lee, S., and Kamens, R. M.: Heterogeneous atmospheric aerosol production by acid-catalyzed particle-phase reactions, Science, 298, 814-817, 2002.

Jang, M. S., Carroll, B., Chandramouli, B., and Kamens, R. M.: Particle growth by acid-catalyzed heterogeneous reactions of organic carbonyls on preexisting aerosols, Environ. Sci. Technol., 37, 3828-3837, 2003.

Jayne, J. T., Leard, D. C., Zhang, X., Davidovits, P., Smith, K. A., Kolb, C. E., and Worsnop, D. R.: Development of an aerosol mass spectrometer for size and composition analysis of submicron particles, Aerosol Sci. Technol., 33, 49-70, 2000.

Jenkin, M.: Modeling the formation and composition of secondary organic aerosol from $\alpha$ - and $\beta$-pinene with O3, Atmos. Chem. Phys., 2004, 1741-1754, 2004 , http://www.atmos-chem-phys.net/2004/1741/2004/.

Jimenez, J. L., Shi, Q., Kolb, C. E., Worsnop, D. R., Yourshaw, I., Seinfeld, J. H., Flagan, R. C., Zhang, X., Smith, K. A., Morris, J. W., and Davidovits, P.: Ambient aerosol sampling using the aerodyne aerosol mass spectrometer, J. Geophys. Res., 108, 8425, doi:10.1029/2001JD001213, 2003.

Kalberer, M., Paulsen, D., Sax, M., Steinbacher, M., Dommen, J., Prevot, A. S. H., Fisseha, R., Weingartner, E., Frankevich, V., Zenobi, R., and Baltensperger, U.: Identification of polymers as major components of atmospheric organic aerosols, Science, 303, 1659-1662, 2004.

Kanakidou, M., Seinfeld, J. H., Pandis, S. N., Barnes, I., Dentener, F. J., Facchini, M. C., VanDingenen, R., Ervens, B., Nenes, A., Nielsen, C. J., Swietlicki, E., Putaud, J. P., Balkanski, Y., Fuzzi, S., Horth, J., Moortgat, G. K., Winterhalter, R., Myhre, C. E. L., Tsigaridis, K., Vignati, E., Stephanou, E. G., and Wilson, J.: Organic aerosol and global climate modelling: A review, Atmos. Chem. Phys., 5, 1053-1123, 2005, http://www.atmos-chem-phys.net/5/1053/2005/.

Katrib, Y., Martin, S. T., Rudich, Y., Davidovits, P., Jayne, J. T., and Worsnop, D. R.: Density changes of aerosol particles as a result of chemical reaction, Atmos. Chem. Phys., 5, 275-291, 2005, http://www.atmos-chem-phys.net/5/275/2005/.

King, S. M., Rosenorn, T., Chen., Q., Shilling, J. E., and Martin, S. T.: CCN activity of mixed sulfate/SOA aerosols, Geophys. Res. Lett., 34, L24806, doi:10.1029/2007GL030390, 2007.

Kleindienst, T. E., Smith, D. F., Li, W., Edney, E. O., Driscoll, D. J., Speer, R. E., and Weathers, W. S.: Secondary organic aerosol formation from the oxidation of aromatic hydrocarbons in the presence of dry submicron ammonium sulfate aerosol, Atmos. Environ., 33, 3669-3681, 1999.

Klotz, B., Sorensen, S., Barnes, I., Becker, K. H., Etzkorn, T., Volkamer, R., Platt, U., Wirtz, K., and Martin-Reviejo, M.: Atmospheric oxidation of toluene in a large-volume outdoor photoreactor: In situ determination of ring-retaining product yields, J. Phys. Chem. A, 102, 10 289-10 299, 1998.

Koch, S., Winterhalter, R., Uherek, E., Kalloff, A., Neeb, P., and Moortgat, G. K.: Formation of new particles in the gas-phase ozonolysis of monoterpenes, Atmos. Environ., 34, 4031-4042, 2000.

Kroll, J. H., Ng, N. L., Murphy, S. M., Flagan, R. C., and Sein- feld, J. H.: Secondary organic aerosol formation from isoprene photooxidation, Environ. Sci. Technol., 40, 1869-1877, 2006.

Kroll, J. H., Chan, A. W. H., Ng, N. L., Flagan, R. C., and Seinfeld, J. H.: Reactions of semivolatile organics and their effects on secondary organic aerosol formation, Environ. Sci. Technol., 41, 3545-3550, 2007.

Liggio, J., Li, S. M., and McLaren, R.: Heterogeneous reactions of glyoxal on particulate matter: Identification of acetals and sulfate esters, Environ. Sci. Technol., 39, 1532-1541, 2005.

Lindinger, W., Hansel, A., and Jordan, A.: On-line monitoring of volatile organic compounds at pptv levels by means of protontransfer-reaction mass spectrometry (PTR-MS) medical applications, food control, and environmental research, Int. J. Mass Spectrom. Ion Processes, 173, 191-241, 1998.

McMurry, P. H. and Grosjean, D.: Gas and aerosol wall losses in Teflon film smog chambers, Environ. Sci. Technol., 19, 11761182, 1985.

Miller, K. A., Siscovick, D. S., Sheppard, L., Shepherd, K., Sullivan, J. H., Anderson, G. L., and Kaufman, J. D.: Long-term exposure to air pollution and incidence of cardiovascular events in women, N. Engl. J. Med., 356, 447-458, 2007.

Ng, N. L., Kroll, J. H., Keywood, M. D., Bahreini, R., Varutbangkul, V., Flagan, R. C., Seinfeld, J. H., Lee, A., and Goldstein, A. H.: Contribution of first- versus second-generation products to secondary organic aerosols formed in the oxidation of biogenic hydrocarbons, Environ. Sci. Technol., 40, 2283-2297, 2006.

Odum, J. R., Hoffmann, T., Bowman, F., Collins, D., Flagan, R. C., and Seinfeld, J. H.: Gas/particle partitioning and secondary organic aerosol yields, Environ. Sci. Technol., 30, 2580-2585, 1996.

Odum, J. R., Jungkamp, T. P. W., Griffin, R. J., Flagan, R. C., and Seinfeld, J. H.: The atmospheric aerosol-forming potential of whole gasoline vapor, Science, 276, 96-99, 1997.

Pandis, S. N., Harley, R. A., Cass, G. R., and Seinfeld, J. H.: Secondary organic aerosol formation and transport, Atmos. Environ., 26, 2269-2282, 1992.

Pankow, J. F.: An absorption-model of gas-particle partitioning of organic-compounds in the atmosphere, Atmos. Environ., 28, 185-188, 1994a.

Pankow, J. F.: An absorption-model of the gas aerosol partitioning involved in the formation of secondary organic aerosol, Atmos. Environ., 28, 189-193, 1994b.

Pathak, R. K., Stanier, C. O., Donahue, N. M., and Pandis, S. N.: Ozonolysis of $\alpha$-pinene at atmospherically relevant concentrations: Temperature dependence of aerosol mass fractions (yields), J. Geophys. Res, 112, D03201, doi:10.1029/2006JD007436, 2007a.

Pathak, R. K., Presto, A. A., Lane, R. E., Stanier, C. O., Donahue, N. M., and Pandis, S. N.: Ozonolysis of $\alpha$-pinene: Parameterization of secondary organic aerosol mass fraction, Atmos. Chem. Phys., 7, 3811-3821, 2007b, http://www.atmos-chem-phys.net/7/3811/2007/.

Paulsen, D., Dommen, J., Kalberer, M., Prevot, A. S. H., Richter, R., Sax, M., Steinbacher, M., Weingartner, E., and Baltensperger, U.: Secondary organic aerosol formation by irradiation of 1,3,5trimethylbenze-NOx-H2O in a new reaction chamber for atmospheric chemistry and physics, Environ. Sci. Technol., 39, 2668 2678, 2005. 
Pope, C. A., Thun, M. J., Namboodiri, M. M., Dockery, D. W., Evans, J. S., Speizer, F. E., and Heath, C. W.: Particulate airpollution as a predictor of mortality in a prospective-study of US adults, Am. J. Respir. Crit. Care Med., 151, 669-674, 1995.

Presto, A. A., Hartz, K. E. H., and Donahue, N. M.: Secondary organic aerosol production from terpene ozonolysis. 2. Effect of $\mathrm{NO}_{x}$ concentration, Environ. Sci. Technol., 39, 7046-7054, 2005.

Presto, A. A. and Donahue, N. M.: Investigation of alpha-pinene plus ozone secondary organic aerosol formation at low total aerosol mass, Environ. Sci. Technol., 40, 3536-3543, 2006.

Robinson, A. L., Donahue, N. M., Shrivastava, M. K., Weitkamp, E. A., Sage, A. M., Grieshop, A. P., Lane, T. E., Pierce, J. R., and Pandis, S. N.: Rethinking organic aerosols: Semivolatile emissions and photochemical aging, Science, 315, 1259-1262, 2007.

Saunders, S. M., Jenkin, M. E., Derwent, R. G., and Pilling, M. J.: Protocol for the development of the master chemical mechanism, MCM v3 (part a): Tropospheric degradation of non-aromatic volatile organic compounds, Atmos. Chem. Phys., 3, 161-180, 2003 , http://www.atmos-chem-phys.net/3/161/2003/.

Seinfeld, J. H., Kleindienst, T. E., Edney, E. O., and Cohen, J. B.: Aerosol growth in a steady-state, continuous flow chamber: Application to studies of secondary aerosol formation, Aerosol Sci. Technol., 37, 728-734, 2003.

Seinfeld, J. H. and Pankow, J. F.: Organic atmospheric particulate material, Annu. Rev. Phys. Chem., 54, 121-140, 2003.

Song, C., Zaveri, R. A., Alexander, M. L., Thorton, J. A., Madronich, S., Ortega, J. V., Zelenyuk, A., Yu, X.-Y., Laskin, A. and Maughan, D. A.: Effect of hydrophobic primary organic aerosols on secondary organic aerosol formation from ozonolysis of $\alpha$-pinene, Geophys. Res. Lett., 37, L20803, doi:10.1029/2007GL030720, 2007.

Takegawa, N., Miyakawa, T., Kondo, Y., Blake, D. R., Kanaya, Y., Koike, M., Fukuda, M., Komazaki, Y., Miyazaki, Y., Shimono, A., and Takeuchi, T.: Evolution of submicron organic aerosol in polluted air exported from Tokyo, Geophys. Res. Lett., 33, L15814, doi:10.1029/2006GL025815, 2006.

Tolocka, M. P., Jang, M., Ginter, J. M., Cox, F. J., Kamens, R. M., and Johnston, M. V.: Formation of oligomers in secondary organic aerosol, Environ. Sci. Technol., 38, 1428-1434, 2004.
Tolocka, M. P., Heaton, K. J., Dreyfus, M. A., Wang, S. Y., Zordan, C. A., Saul, T. D., and Johnston, M. V.: Chemistry of particle inception and growth during alpha-pinene ozonolysis, Environ. Sci. Technol., 40, 1843-1848, 2006.

Tsigaridis, K. and Kanakidou, M.: Secondary organic aerosol importance in the future atmosphere, Atmos. Environ., 41, 46824692, 2007.

VanReken, T. M., Greenberg, J. P., Harley, P. C., Buenther, A. B., and Smith, J. N.: Direct measurement of particle formation and growth from the oxidation of biogenic emissions, Atmos. Chem. Phys., 6, 4403-4413, 2006,

http://www.atmos-chem-phys.net/6/4403/2006/.

Verheggen, B., Mozurkewich, M., Caffrey, P., Frick, G., Hoppel, W., and Sullivan, W.: $\alpha$-pinene oxidation in the presence of seed aerosol: Estimates of nucleation rates, growth rates, and yield, Environ. Sci. Technol., 41(17), 6046-6051, 2007.

Volkamer, R., Jimenez, J. L., San Martini, F., Dzepina, K., Zhang, Q., Salcedo, D., Molina, L. T., Worsnop, D. R., and Molina, M. J.: Secondary organic aerosol formation from anthropogenic air pollution: Rapid and higher than expected, Geophys. Res. Lett., 33, L17811, doi:10.1029/2006GL026899, 2006.

Yu, J., Cocker, D. R., Griffin, R. J., Flagan, R. C., and Seinfeld, J. H.: Gas-phase ozone oxidation of monoterpenes: Gaseous and particulate products, J. Atmos. Chem., 34, 207-258, 1999.

Zhang, Q., Canagaratna, M. R., Jayne, J. T., Worsnop, D. R., and Jimenez, J.-L.: Time- and size-resolved chemical compositions of submicron particles in Pittsburgh: Implications for aerosol sources and processes, J. Geophys. Res., 110, D70S79, doi:10.1029/2004JD004649, 2005.

Zhang, Q., Jimenez, J. L., Canagaratna, M. R., Allan, J. D., Coe, H., Ulbrich, I., Alfarra, M. R., Takami, A., Middlebrook, A. M., Sun, Y. L., Dzepina, K., Dunlea, E., Docherty, K., DeCarlo, P. F., Salcedo, D., Onasch, T., Jayne, J. T., Miyoshi, T., Shimono, A., Hatakeyama, S., Takegawa, N., Kondo, Y., Schneider, J., Drewnick, F., Borrmann, S., Weimer, S., Demerjian, K., Williams, P., Bower, K., Bahreini, R., Cottrell, L., Griffin, R. J., Rautianinen, J., Sun, J. Y., Zhang, Y. M., and Worsnop, D. R.: Ubiquity and dominance of oxygenated species in organic aerosols in anthropogenically-influenced nothern hemisphere midlatitudes, Geophys. Res. Lett., 34, L13801, doi:10.1029/2007GL029979, 2007. 